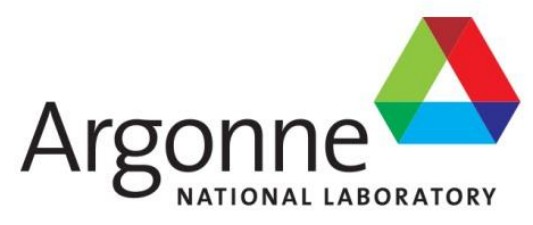

\title{
Mo Recovery Updates and Physical Properties of Uranyl Sulfate Solutions
}

Chemical Science and Engineering Division 


\begin{abstract}
About Argonne National Laboratory
Argonne is a U.S. Department of Energy laboratory managed by UChicago Argonne, LLC under contract DE-AC02-06CH11357. The Laboratory's main facility is outside Chicago, at 9700 South Cass Avenue, Argonne, Illinois 60439. For information about Argonne and its pioneering science and technology programs, see www.anl.gov.
\end{abstract}

\title{
DOCUMENT AVAILABILITY
}

Online Access: U.S. Department of Energy (DOE) reports produced after 1991 and a growing number of pre-1991 documents are available free via DOE's SciTech Connect (http://www.osti.gov/scitech/)

Reports not in digital format may be purchased by the public from the National Technical Information Service (NTIS):

U.S. Department of Commerce

National Technical Information Service

5301 Shawnee Rd

Alexandra, VA 22312

www.ntis.gov

Phone: (800) 553-NTIS (6847) or (703) 605-6000

Fax: (703) 605-6900

Email: orders@ntis.gov

Reports not in digital format are available to DOE and DOE contractors from the Office of Scientific and Technical Information (OSTI):

U.S. Department of Energy

Office of Scientific and Technical Information

P.O. Box 62

Oak Ridge, TN 37831-0062

www.osti.gov

Phone: (865) 576-8401

Fax: (865) 576-5728

Email: reports@osti.gov

\footnotetext{
Disclaimer

This report was prepared as an account of work sponsored by an agency of the United States Government. Neither the United States Government nor any agency thereof, nor UChicago Argonne, LLC, nor any of their employees or officers, makes any warranty, express or implied, or assumes any legal liability or responsibility for the accuracy, completeness, or usefulness of any information, apparatus, product, or process disclosed, or represents that its use would not infringe privately owned rights. Reference herein to any specific commercial product, process, or service by trade name, trademark, manufacturer, or otherwise, does not necessarily constitute or imply its endorsement, recommendation, or favoring by the United States Government or any agency thereof. The views and opinions of document authors expressed herein do not necessarily state or reflect those of the United States Government or any agency thereof, Argonne National Laboratory, or UChicago Argonne, LLC.
} 


\section{Mo Recovery Updates and Physical Properties of Uranyl Sulfate Solutions}

by

Amanda J. Youker, Dominique C. Stepinski, Lei Ling, and George F. Vandegrift Chemical Science and Engineering Division, Argonne National Laboratory

prepared for

U.S. Department of Energy, National Nuclear Security Administration, Office of Defense Nuclear Nonproliferation

September 14, 2012 



\section{CONTENTS}

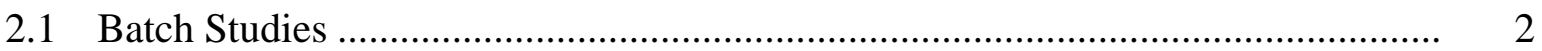

2.2 Preparation of Mo-99 Spike Solution .............................................................. 2

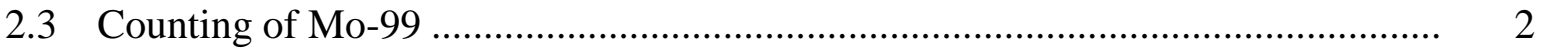

2.4 Inductively Coupled Optical Emission Spectroscopy........................................ 3

2.5 Column Design Parameters............................................................................... 3

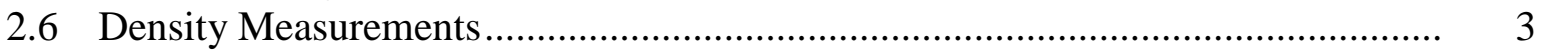

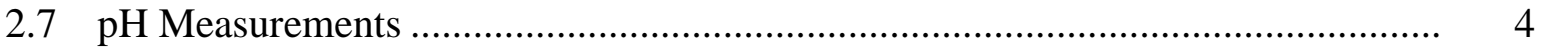

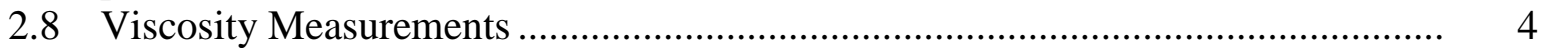

2.9 Thermal Conductivity and Specific Heat Measurements .................................... 4

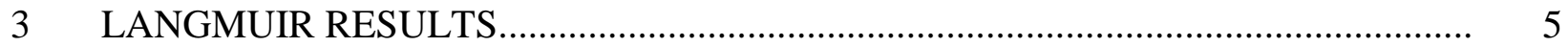

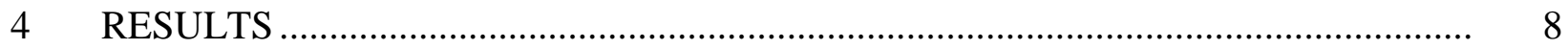

4.1 Plant-Scale Column Designs....................................................................... 8

4.2 Downscale Column Experiments................................................................. 10

4.3 Density Results ................................................................................... 13

$4.4 \mathrm{pH}$ Measurements ...................................................................................... 13

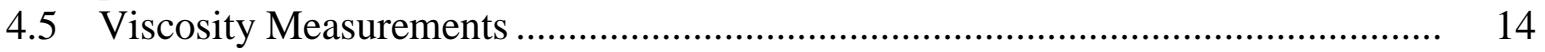

4.6 Thermal Conductivity and Specific Heat Measurements .................................. 15

5 CONCLUSIONS AND FUTURE WORK ............................................................. 17

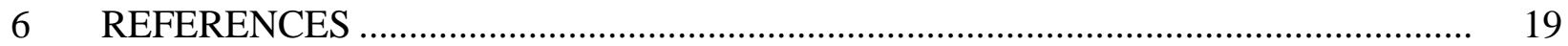

APPENDIX A: PLANT-SCALE COLUMN DESIGNS FOR THE POTENTIAL SHINE TARGET SOLUTION CONFIGURATIONS WITH LOADING TIMES OF 4 AND 6 HOURS

APPENDIX B: pH MEASUREMENTS FOR URANYL SULFATE SOLUTIONS WITH DIFFERENT INITIAL $\mathrm{pH}$ VALUES AND DIFFERENT SULFATE CONCENTRATIONS

APPENDIX C: VISCOSITY MEASUREMENTS FOR URANYL SULFATE SOLUTIONS. 


\section{FIGURES}

1 Plot of Langmuir-Type Adsorption on a Titania Sorbent in the Presence

of a $150 \mathrm{~g}-\mathrm{U} / \mathrm{L}$ Uranyl Sulfate Solution with Origin Fitting at $60^{\circ} \mathrm{C}$

2 Plot of Langmuir-Type Adsorption on a Titania Sorbent in the Presence

of a $90 \mathrm{~g}$-U/L Uranyl Sulfate Solution with Origin Fitting at $60^{\circ} \mathrm{C}$

3 Plot of Langmuir-Type Adsorption on a Titania Sorbent in the Presence

of a $130 \mathrm{~g}$-U/L Uranyl Sulfate Solution with Origin Fitting at $80^{\circ} \mathrm{C}$

4 A Plot of $\mathrm{pH}$ Versus Temperature for Uranyl Sulfate Solutions

5 A Plot of Viscosity Versus Temperature for Uranyl Sulfate Solutions

16

\section{TABLES}

1 Calculated Values for the Density and Viscosity of Uranyl Sulfate Solutions at $60^{\circ} \mathrm{C}$ and $80^{\circ} \mathrm{C}$

2 The $a$ and $b$ Parameters for the Five Different Target Solution Configurations

3 Target Solution Configurations Being Considered by SHINE

4 Preliminary Designs for Recovery of Mo from $395 \mathrm{~L}$ of $90 \mathrm{~g}-\mathrm{U} / \mathrm{L}$,

$1.78 \times 10^{-3} \mathrm{mM} \mathrm{Mo}$, at $60^{\circ} \mathrm{C}$

5 Preliminary Designs for Recovery of Mo from 257.7 L of 104.2 g-U/L, $2.35 \times 10^{-3} \mathrm{mM} \mathrm{Mo}$, at $60^{\circ} \mathrm{C}$.

6 Preliminary Designs for Recovery of Mo from $262 \mathrm{~L}$ of $130 \mathrm{~g}-\mathrm{U} / \mathrm{L}$, $2.10 \times 10^{-3} \mathrm{mM} \mathrm{Mo}$, at $80^{\circ} \mathrm{C}$.

7 Preliminary Designs for Recovery of Mo from 178.3 L of $124.8 \mathrm{~g}-\mathrm{U} / \mathrm{L}$, $2.98 \times 10^{-3} \mathrm{mM} \mathrm{Mo}$, at $60^{\circ} \mathrm{C}$

8 Preliminary Designs for Recovery of Mo from 142.3 L of $146.8 \mathrm{~g}-\mathrm{U} / \mathrm{L}$, $3.55 \times 10^{-3} \mathrm{mM} \mathrm{Mo}$, at $60^{\circ} \mathrm{C}$

9 Results for the Downscale Column Experiments for the Five Different Target Solution Configurations

10 Density Values Measured for Uranyl Sulfate Solutions 


\section{TABLES (Cont.)}

$11 \quad$ Calculated and Measured Density Values ............................................................... 14

$12 \mathrm{pH}$ Values Measured for $\mathrm{pH} 1$ Buffer as a Function of Temperature........................... 14

13 Calculated and Measured Viscosity Values............................................................. 16

A-1 Preliminary Designs for Recovery of Mo from $395 \mathrm{~L}$ of $90 \mathrm{~g}-\mathrm{U} / \mathrm{L}$,

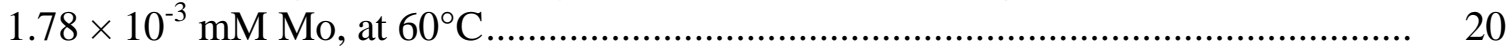

A-2 Preliminary Designs for Recovery of Mo from $395 \mathrm{~L}$ of $90 \mathrm{~g}-\mathrm{U} / \mathrm{L}$, $1.78 \times 10^{-3} \mathrm{mM} \mathrm{Mo}$, at $60^{\circ} \mathrm{C}$

A-3 Preliminary Designs for Recovery of Mo from $257.7 \mathrm{~L}$ of $104.2 \mathrm{~g}-\mathrm{U} / \mathrm{L}$, $2.35 \times 10^{-3} \mathrm{mM} \mathrm{Mo}$, at $60^{\circ} \mathrm{C}$

A-4 Preliminary Designs for Recovery of Mo from $257.7 \mathrm{~L}$ of $104.2 \mathrm{~g}-\mathrm{U} / \mathrm{L}$, $2.35 \times 10^{-3} \mathrm{mM} \mathrm{Mo}$, at $60^{\circ} \mathrm{C}$

A-5 Preliminary Designs for Recovery of Mo from $178.3 \mathrm{~L}$ of $124.8 \mathrm{~g}-\mathrm{U} / \mathrm{L}$, $2.98 \times 10^{-3} \mathrm{mM} \mathrm{Mo}$, at $60^{\circ} \mathrm{C}$

A-6 Preliminary Designs for Recovery of Mo from $178.3 \mathrm{~L}$ of $124.8 \mathrm{~g}-\mathrm{U} / \mathrm{L}$, $2.98 \times 10^{-3} \mathrm{mM} \mathrm{Mo}$, at $60^{\circ} \mathrm{C}$.

A-7 Preliminary Designs for Recovery of Mo from $262 \mathrm{~L}$ of $130 \mathrm{~g}-\mathrm{U} / \mathrm{L}$, $2.10 \times 10^{-3} \mathrm{mM} \mathrm{Mo}$, at $80^{\circ} \mathrm{C}$

A-8 Preliminary Designs for Recovery of Mo from $262 \mathrm{~L}$ of $130 \mathrm{~g}-\mathrm{U} / \mathrm{L}$, $2.10 \times 10^{-3} \mathrm{mM}$ Mo, at $80^{\circ} \mathrm{C}$.

A-9 Preliminary Designs for Recovery of Mo from $142.3 \mathrm{~L}$ of $146.8 \mathrm{~g}-\mathrm{U} / \mathrm{L}$, $3.55 \times 10^{-3} \mathrm{mM} \mathrm{Mo}$, at $60^{\circ}$

A-10 Preliminary Designs for Recovery of Mo from $142.3 \mathrm{~L}$ of $146.8 \mathrm{~g}-\mathrm{U} / \mathrm{L}$, $3.55 \times 10^{-3} \mathrm{mM}$ Mo, at $60^{\circ} \mathrm{C}$.

B-1 pH Measurements for Uranyl Sulfate Solutions as a Function of Temperature and Uranium Concentration

C-1 Viscosity Measurements for Uranyl Sulfate Solutions as a Function of Temperature and Uranium Concentration 


\section{Mo RECOVERY UPDATES AND PHYSICAL PROPERTIES OF URANYL SULFATE SOLUTIONS}

\section{INTRODUCTION}

Argonne National Laboratory (Argonne) is assisting Morgridge Institute for Research (MIR) in their efforts to develop SHINE, which is an accelerator-driven process that will use a uranyl sulfate solution for the production of molybdenum-99 (Mo-99). An integral part of the process is the development of a plant-scale column for the separation and recovery of Mo-99. Argonne has collected data from batch studies and small-scale column experiments to input into VERSE (Versatile Reaction Separation), which was developed by Dr. Linda Wang at Purdue University, to design large-scale separation processes using data obtained on a much smaller scale. Plant-scale column designs have been generated for several different target solution configurations with uranium concentrations varying from 90 to $150 \mathrm{~g}$-U/L; Mo concentrations ranging from $1.73 \times 10^{-3}$ to $3.55 \times 10^{-3} \mathrm{mM}$; and solution volumes varying between 142 and 395 L. Direct downscale column results confirm the validity of most of the plant-scale designs because typically less than $1 \%$ Mo is found in the effluent and $90-100 \pm 5 \%$ Mo can be recovered under the appropriate stripping conditions.

To design a Mo-recovery system for the SHINE project, batch, breakthrough, and pulse tests were conducted to determine isotherm, mass transfer, and system parameters. The VERSE program was used to calculate the mass-transfer zone under various loading times and velocities to design Mo separation and recovery columns using a pure titania sorbent with $110-\mu \mathrm{m}$ particles and $60-\AA$ pores. The plant-scale column designs assume a temperature of $60^{\circ} \mathrm{C}$ for most configurations and $80^{\circ} \mathrm{C}$ for feed solutions containing $130 \mathrm{~g}-\mathrm{U} / \mathrm{L}$ uranyl sulfate. VERSEdesigned recovery systems have been tested and verified in laboratory-scale experiments, and this approach has been shown to be very successful.

In addition to the development of a plant-scale column design for the separation and recovery of Mo-99, Argonne measured several physical properties of uranyl sulfate solutions as a function of temperature and uranium concentration. SHINE needs data to model various target solution configurations in order to see how properties such as density, $\mathrm{pH}$, viscosity, thermal conductivity, and specific heat change with temperature and vary for solutions with different uranium concentrations. 


\section{EXPERIMENTAL}

\subsection{BATCH STUDIES}

The uptake of Mo(VI) was determined by equilibrating $1 \mathrm{~mL}$ of a Mo-99 spiked aqueous solution with a known amount $(10 \pm 1 \mathrm{mg})$ of sorbent for 24 hours at $60^{\circ} \mathrm{C}$ or $80^{\circ} \mathrm{C}$ using a thermostated shaker bath. Aqueous solutions contained tracer Mo-99 and $10^{-10}$ to $10^{-4} \mathrm{M}$ Mo was added as $\mathrm{Na}_{2} \mathrm{MoO}_{4} \cdot 2 \mathrm{H}_{2} \mathrm{O}$ in the presence of uranyl sulfate (90-150 g-U/L). After equilibration, the solution was withdrawn and filtered using a syringe fitted with a $0.22-\mu \mathrm{m}$ pore size PVDF (polyvinylidene fluoride) membrane filter.

\subsection{PREPARATION OF Mo-99 SPIKE SOLUTION}

Mo-99 was obtained from a spent Tc-99m generator (provided by Hot Shots Nuclear Medicine), which we receive on a weekly basis. The initial activity of Mo-99 in a generator is typically between 1 and $10 \mathrm{Ci}$. However, we receive a Tc-99m generator when the activity remaining in the generator is insufficient for patient administration. Typically, a spent Tc-99m generator contains $0.1-0.3 \mathrm{Ci}$ of Mo-99, which is more than enough for our tracer batch and column work.

Mo-99 was removed from the generator by placing a serum vial containing 1-M NH $\mathrm{N}_{4} \mathrm{OH}$ on the needle labeled "Saline Charge." After that, an evacuated serum vial was placed on the needle labeled "Receiver." When no more bubbles appeared in the Receiver vial, the Receiver bottle was removed from the generator. The Mo-99 spiked solution was prepared by bringing the solution to dryness on a hot plate, and re-dissolving it in $0.1-\mathrm{M} \mathrm{H}_{2} \mathrm{SO}_{4}$.

\subsection{COUNTING OF Mo-99}

The amount of activity in the aqueous samples was determined using a germanium detector. Mo-99 was quantified by measurement of its $739 \mathrm{keV} \gamma$-ray. The activity of Mo-99 in each sample was corrected for decay. The extent of radionuclide uptake in batch studies was expressed in terms of a distribution coefficient, $K_{d}$, shown in equation (1):

$$
K_{d}=\left(\frac{A_{o}-A_{s}}{W}\right) / \frac{A_{s}}{V} .
$$

Here, $A_{0}$ and $A_{s}$ represent the aqueous phase activity ( $\mu \mathrm{Ci}$ ) before and after equilibration, respectively; $W$ is the dry weight of the sorbent $(\mathrm{g})$; and $V$ is the volume of the aqueous phase (mL). 


\subsection{INDUCTIVELY COUPLED OPTICAL EMISSION SPECTROSCOPY (ICP-OES)}

Inductively coupled optical emission spectroscopy was used to determine the concentration of uranium, and the error associated with these measurements is $\pm 5 \%$.

\subsection{COLUMN DESIGN PARAMETERS}

The parameters and physical properties of uranyl sulfate given below were input into VERSE to design the plant-scale columns for the five different target solution configurations being considered by SHINE. Table 1 shows the calculated density and viscosity values for the different uranyl sulfate solutions.

1. The sorbent utilized for the Mo-recovery column is S110, a pure titania sorbent with $110-\mu \mathrm{m}$ particles and $60-\AA$ pores.

2. Langmuir isotherm parameters were estimated from Mo batch data measured for solutions with varying Mo concentrations in solutions containing 90 and $150 \mathrm{~g}-\mathrm{U} / \mathrm{L}$ uranyl sulfate at $60^{\circ} \mathrm{C}$ and $130 \mathrm{~g}-\mathrm{U} / \mathrm{L}$ uranyl sulfate at $80^{\circ} \mathrm{C}$.

3. The Brownian diffusivity $\left(D_{\infty}\right)$ value of $\mathrm{HMoO}_{4}{ }^{-}$in water at $25^{\circ} \mathrm{C}$ (viscosity $=0.8851 \mathrm{Cp}$ ) was reported to be $8.3 \times 10^{-4} \mathrm{~cm}^{2} / \mathrm{min}(\mathrm{Xu}$ and Pruess 2001; Marcus 1997).

4. The density of a $130 \mathrm{~g}-\mathrm{U} / \mathrm{L}$ uranyl-sulfate solution at $\mathrm{pH} 1$ was determined experimentally to be $1.16 \mathrm{~g} / \mathrm{mL}$ at $80^{\circ} \mathrm{C}$. The densities of the remaining solutions were calculated by fitting data found in the literature (see Table 1) (Orban et al. 1956; McDuffie 1960).

5. Viscosities for the target solutions were estimated by fitting published data obtained at 20.0, 30.0, 44.8, 59.8 75.0, and $90.0^{\circ} \mathrm{C}$ (see Table 1) (Rhodes and Barbour 1923).

6. Eb, axial dispersion estimated using Chung and Wen (1968) correlation.

7. $k f$, mass transfer coefficient estimated using Wilson and Geankoplis (1966).

8. Sorbent intra-particle voidage was obtained from the manufacturer, $\varepsilon p=0.40$. Total void fraction, $\varepsilon t$, was determined experimentally to be 0.608 and interparticle voidage, $\varepsilon b=0.35$, value was calculated $[\varepsilon t=\varepsilon b+\varepsilon p \times(1-\varepsilon b)]$.

\subsection{DENSITY MEASUREMENTS}

The densities of uranyl sulfate solutions containing approximately 90-140 g-U/L were determined using a Mettler-Toledo density meter. Measurements were made from 20 to $80^{\circ} \mathrm{C}$. 
TABLE 1 Calculated Values for the Density and Viscosity of Uranyl Sulfate Solutions at $60^{\circ} \mathrm{C}$ and $80^{\circ} \mathrm{C}$

\begin{tabular}{llcc}
\hline & & & \\
g-U/L & $\rho(\mathrm{g} / \mathrm{mL})$ & $\mu(\mathrm{Cp})$ & Temperature $\left({ }^{\circ} \mathrm{C}\right)$ \\
\hline & & & \\
90 & 1.1 & 0.59 & 60 \\
104.2 & 1.12 & 0.61 & 60 \\
130 & $1.16^{\mathrm{a}}$ & 0.47 & 80 \\
124.8 & 1.15 & 0.64 & 60 \\
146.8 & 1.18 & 0.68 & 60 \\
\hline
\end{tabular}

a Value was determined experimentally using a Mettler-Toledo density meter.

The errors associated with these measurements are $\pm 0.02 \mathrm{~g} / \mathrm{mL}$ at $20^{\circ} \mathrm{C}$ and $\pm 0.05 \mathrm{~g} / \mathrm{mL}$ for the remaining temperatures.

\section{7 pH MEASUREMENTS}

The $\mathrm{pH}$ values of several uranyl sulfate solutions containing approximately 90-140 g-U/L were determined using an Orion-Ultra $\mathrm{pH}$ electrode and meter. The electrode was calibrated with $\mathrm{pH} 1$ and $\mathrm{pH} 3$ buffers. In addition, prior to each uranyl sulfate measurement, the $\mathrm{pH}$ of the $\mathrm{pH} 1$ buffer was measured as a function of temperature from approximately $22-80^{\circ} \mathrm{C}$, and adjustments to the $\mathrm{pH}$ measurements for the uranyl sulfate solutions over the temperature range of approximately $22-80^{\circ} \mathrm{C}$ were made accordingly.

\subsection{VISCOSITY MEASUREMENTS}

The viscosities of uranyl sulfate solutions containing approximately $90-140 \mathrm{~g}-\mathrm{U} / \mathrm{L}$ were determined from approximately 22 to $80^{\circ} \mathrm{C}$ using a Cambridge viscometer. The errors associated with these measurements are $\pm 0.3 \%$ for temperatures between 22 and $60^{\circ} \mathrm{C}$ and $\pm 2 \%$ for temperatures between 70 and $80^{\circ} \mathrm{C}$.

\subsection{THERMAL CONDUCTIVITY AND SPECIFIC HEAT MEASUREMENTS}

A Thermtest thermal conductivity meter that also measures specific heat (when the density of the solution is known) was purchased. Unfortunately, the materials used to construct the sensor were not corrosion resistant to $\mathrm{pH} 1$ uranyl sulfate solutions. The manufacturer stated silicone caulk could be used to prevent further corrosion. However, generating a new calibration curve for the sensor with the silicone caulk was not easy or reliable. Thermtest is manufacturing a custom sensor that will be corrosion resistant. As a result, the thermal conductivity and specific heat measurements will not be available until Argonne receives the new sensor. 


\section{LANGMUIR RESULTS}

The uptake of Mo was determined in a batch mode as a function of increasing Mo concentration. It has been shown previously that Mo adsorption on titania sorbents follows Langmuir behavior (Knopf 2003). There are four basic assumptions associated with the Langmuir model:

1. All adsorption sites are equal.

2. Adsorbing species do not interact with each other.

3. The adsorption mechanism does not vary for the same species.

4. The adsorbing species will form a single monolayer and only occupy free adsorption sites (Knopf 2003).

The model for Langmuir-type adsorption is shown by equation (2), where $q_{i}$ represents the amount of species $i$ adsorbed on the sorbent, $a_{i}$ is the linear isotherm parameter, $b_{i}$ is the nonlinear isotherm parameter, and $C_{i}$ represents the aqueous-phase concentration of $i$ in equilibrium with $\mathrm{q}_{\mathrm{i}}$ (Langmuir 1916).

$$
q_{i}=\frac{a_{i} * C_{i}}{\left(1+b_{i} C_{i}\right)}
$$

Langmuir-type data were obtained in solutions containing 90 and $150 \mathrm{~g}-\mathrm{U} / \mathrm{L}$ uranyl sulfate at $60^{\circ} \mathrm{C}$ and $130 \mathrm{~g}-\mathrm{U} / \mathrm{L}$ at $80^{\circ} \mathrm{C}$. Figures 1,2 , and 3 show the Langmuir data obtained in uranyl sulfate solutions containing $150 \mathrm{~g}-\mathrm{U} / \mathrm{L}$ at $60^{\circ} \mathrm{C}, 90 \mathrm{~g}-\mathrm{U} / \mathrm{L}$ at $60^{\circ} \mathrm{C}$, and $130 \mathrm{~g}-\mathrm{U} / \mathrm{L}$ at $80^{\circ} \mathrm{C}$. The data were fit to the Langmuir model using Origin 8.5.1. Table 2 shows the $a$ linear and $b$ nonlinear parameters input into VERSE to design the plant-scale columns for the five different target solution configurations. The same $a$ and $b$ values obtained in a $90 \mathrm{~g}-\mathrm{U} / \mathrm{L}$ uranyl sulfate solution were used to generate column designs for a $104.2 \mathrm{~g}$-U/L uranyl sulfate solution. In addition, the same $a$ and $b$ values obtained in a $150 \mathrm{~g}-\mathrm{U} / \mathrm{L}$ uranyl sulfate solution were used to generate column designs for a 124.8 and a $146.8 \mathrm{~g}$-U/L uranyl sulfate solution. 


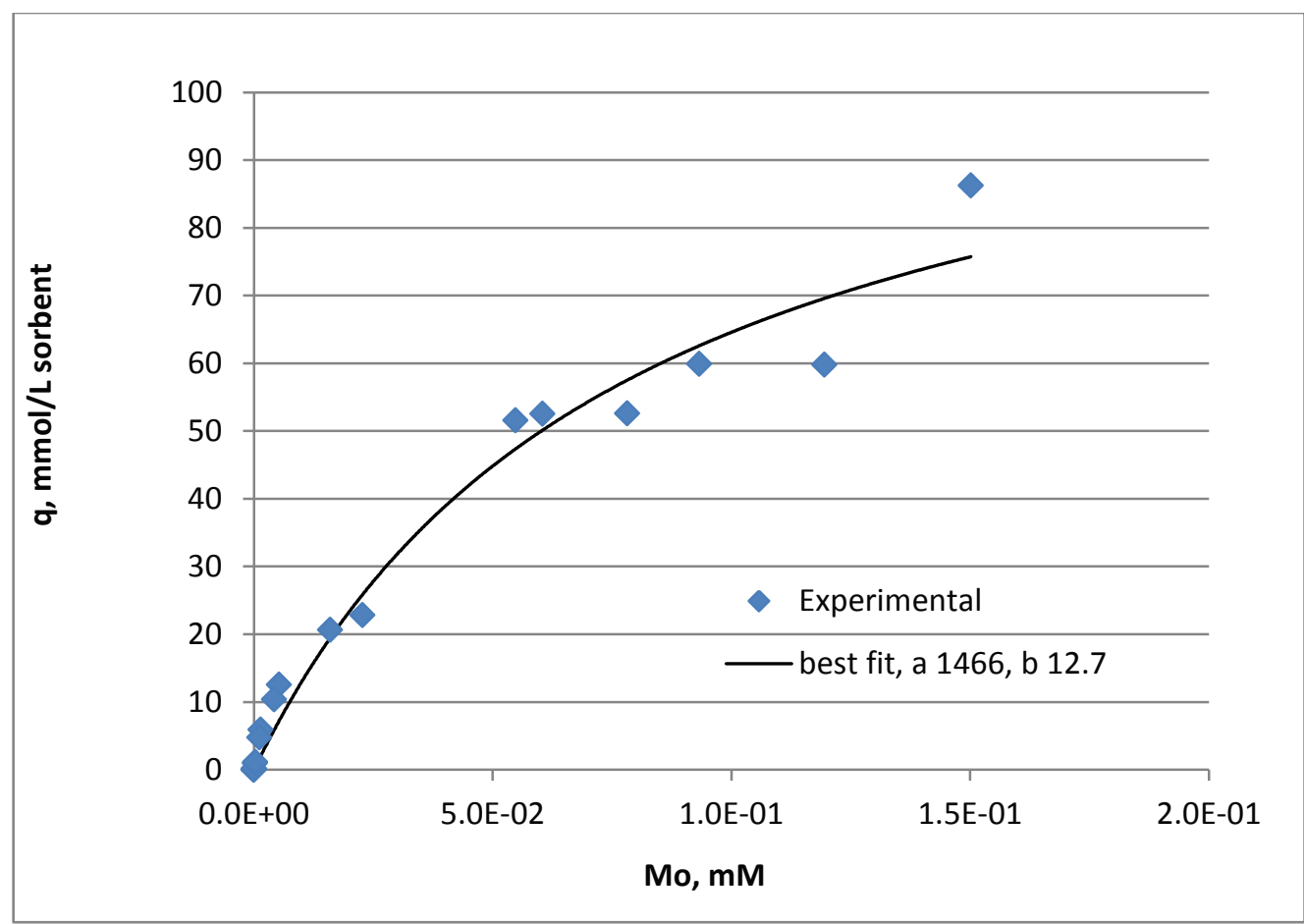

FIGURE 1 Plot of Langmuir-Type Adsorption on a Titania Sorbent in the Presence of a $150 \mathrm{~g}-\mathrm{U} / \mathrm{L}$ Uranyl Sulfate Solution with Origin Fitting at $60^{\circ} \mathrm{C}$

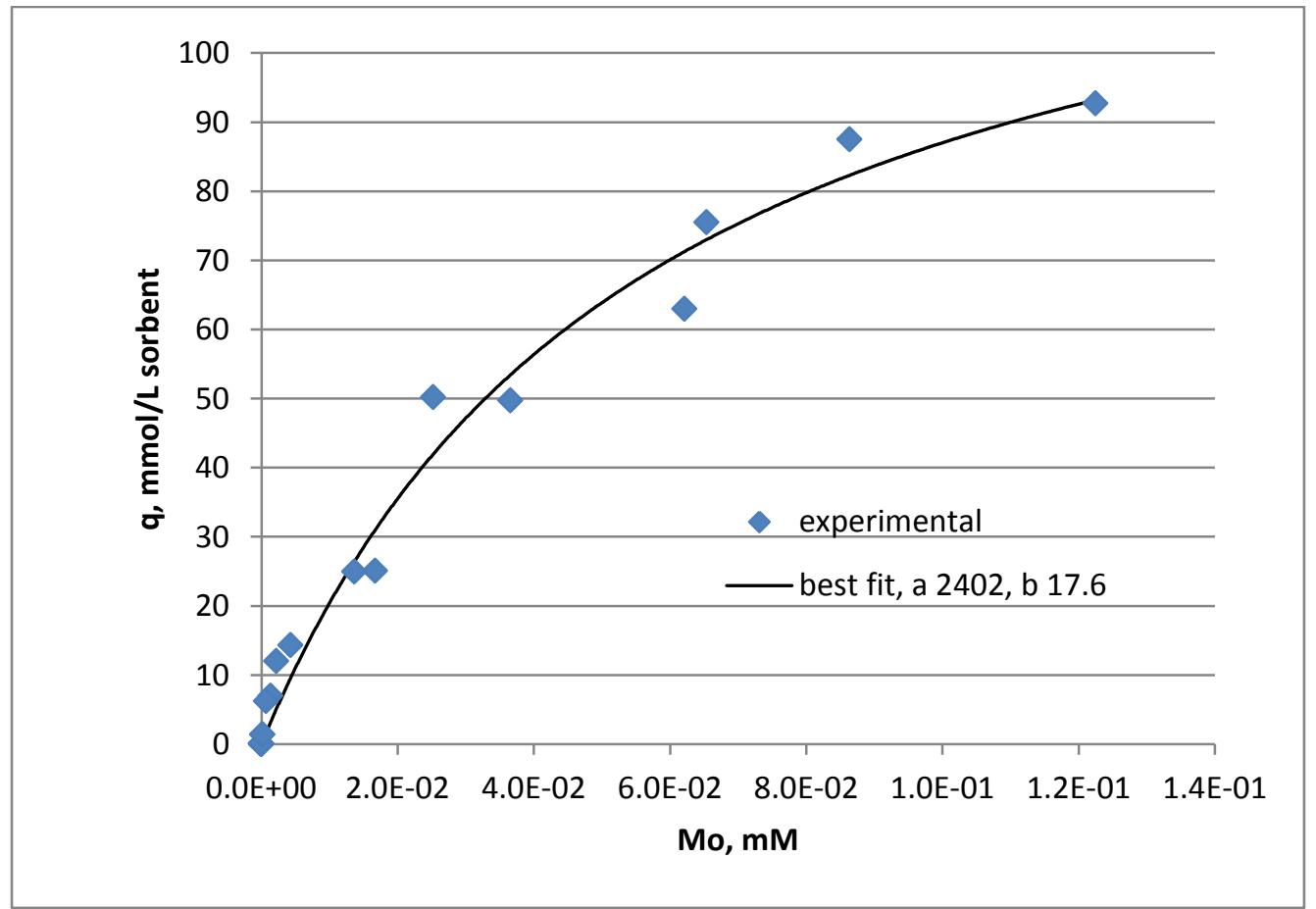

FIGURE 2 Plot of Langmuir-Type Adsorption on a Titania Sorbent in the Presence of a $90 \mathrm{~g}-\mathrm{U} / \mathrm{L}$ Uranyl Sulfate Solution with Origin Fitting at $60^{\circ} \mathrm{C}$ 


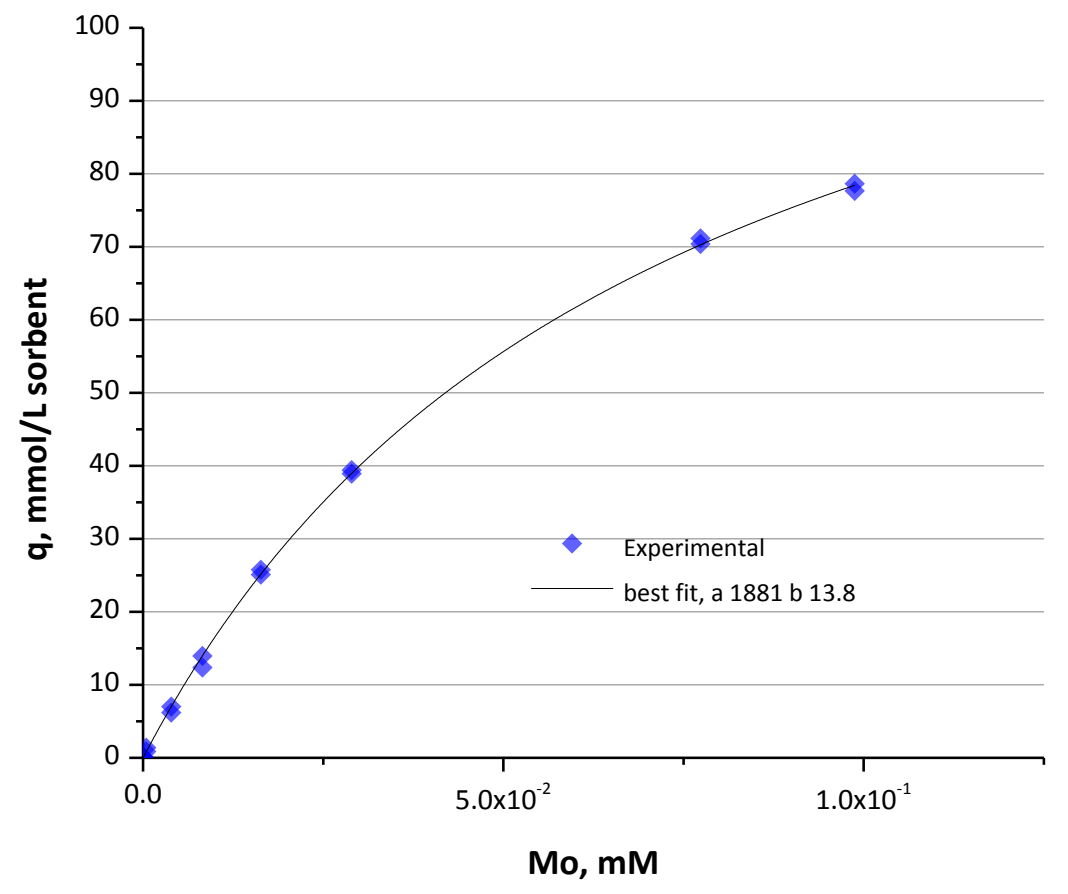

FIGURE 3 Plot of Langmuir-Type Adsorption on a Titania Sorbent in the Presence of a $130 \mathrm{~g}-\mathrm{U} / \mathrm{L}$ Uranyl Sulfate Solution with Origin Fitting at $80^{\circ} \mathrm{C}$

TABLE 2 The $a$ and $b$ Parameters for the Five Different Target Solution Configurations

\begin{tabular}{lccc}
\hline $\begin{array}{c}\text { U Concentration } \\
(\mathrm{g}-\mathrm{U} / \mathrm{L})\end{array}$ & $\begin{array}{c}\text { Temperature } \\
\left({ }^{\circ} \mathrm{C}\right)\end{array}$ & $\begin{array}{c}\text { Langmuir } \\
a \text { value }\end{array}$ & $\begin{array}{c}\text { Langmuir } \\
b \text { value }\left(\mathrm{mM}^{-1}\right)\end{array}$ \\
\hline & & & \\
90 & 60 & 2402 & 17.6 \\
104.2 & 60 & 2402 & 17.6 \\
124.8 & 60 & 1466 & 12.7 \\
130 & 80 & 1881 & 13.8 \\
146.8 & 60 & 1466 & 12.7 \\
\hline
\end{tabular}




\section{RESULTS}

\subsection{PLANT-SCALE COLUMN DESIGNS}

Table 3 shows the five different target solution configurations being considered by SHINE Medical Technologies for the production of Mo-99. Potential column designs were developed for loading the target solution onto the column over periods of 2, 4, and 6 hours. Plant-scale column designs for the different configurations with loading times of 4 and 6 hours are shown in Appendix I. In the tables shown below, the mass-transfer zone (MTZ) was calculated for each column diameter based on the linear velocity required to complete loading the column in the specified time period. The column length was increased by $10 \%$ above the MTZ and rounded up to the nearest centimeter to account for system parameter uncertainties. The column volume, mass of sorbent, pressure drop, and sorbent loading were calculated from the column geometry. Tables $4-8$ show the potential column designs for the different configurations with a loading time of 2 hours.

TABLE 3 Target Solution Configurations Being Considered by SHINE

\begin{tabular}{llcccc}
\hline $\begin{array}{c}\text { Uranyl Sulfate, } \\
(\mathrm{g}-\mathrm{U} / \mathrm{L})\end{array}$ & Vol. (L) & $\begin{array}{c}\text { Fission Power } \\
(\mathrm{kW})\end{array}$ & Mo (mmol) & Mo $(\mathrm{mM})$ & Mo-99 (Ci) \\
\hline & & & & & \\
90 & 395 & 112.7 & $7.03 \times 10^{-1}$ & $1.78 \times 10^{-3}$ & 5000 \\
104.2 & 257.7 & 97.2 & $6.06 \times 10^{-1}$ & $2.35 \times 10^{-3}$ & 4313 \\
130 & 262 & 87.5 & $5.50 \times 10^{-1}$ & $2.10 \times 10^{-3}$ & 3882 \\
124.8 & 178.3 & 85.1 & $5.31 \times 10^{-1}$ & $2.98 \times 10^{-3}$ & 3776 \\
146.8 & 142.3 & 80.9 & $5.05 \times 10^{-1}$ & $3.55 \times 10^{-3}$ & 3589 \\
\hline
\end{tabular}

TABLE 4 Preliminary Designs for Recovery of Mo from $395 \mathrm{~L}$ of $90 \mathrm{~g}-\mathrm{U} / \mathrm{L}$, $1.78 \times 10^{-3} \mathrm{mM}$ Mo, at $60^{\circ} \mathrm{C}(\mathrm{S110}, 99.9 \%$ recovery, 2-hour loading time, $3.3 \mathrm{~L} / \mathrm{min})$

\begin{tabular}{cccccccc}
\hline Column & $\begin{array}{c}\text { Velocity } \\
(\mathrm{cm} / \mathrm{min})\end{array}$ & $\begin{array}{c}\text { MTZ } 0.1 \% \\
(\mathrm{~cm})\end{array}$ & $\begin{array}{c}\text { Column } \\
\text { Length } \\
(\mathrm{cm})\end{array}$ & $\begin{array}{c}\text { Column } \\
\text { Volume } \\
(\mathrm{mL})\end{array}$ & $\begin{array}{c}\text { Sorbent } \\
\text { Weight } \\
(\mathrm{g})\end{array}$ & $\begin{array}{c}\Delta \mathrm{P} \\
(\mathrm{atm})\end{array}$ & $\begin{array}{c}\text { Mo-99/Sorbent } \\
\text { Mass (Ci/g) }\end{array}$ \\
\hline & & & & & & & \\
12 & 29.1 & 18.25 & 20 & 2262 & 2941 & 0.87 & 1.70 \\
15 & 18.63 & 11.77 & 13 & 2297 & 2986 & 0.36 & 1.67 \\
20 & 10.48 & 6.73 & 8 & 2513 & 3267 & 0.13 & 1.53 \\
25 & 6.71 & 4.39 & 5 & 2454 & 3191 & 0.05 & 1.57 \\
30 & 4.66 & 3.13 & 4 & 2827 & 3676 & 0.03 & 1.36 \\
\hline
\end{tabular}


TABLE 5 Preliminary Designs for Recovery of Mo from $257.7 \mathrm{~L} \mathrm{of} 104.2 \mathrm{~g}-\mathrm{U} / \mathrm{L}$, $2.35 \times 10^{-3} \mathrm{mM} \mathrm{Mo}$, at $60^{\circ} \mathrm{C}(\mathrm{S110}, 99.9 \%$ recovery, 2-hour loading time, $2.1 \mathrm{~L} / \mathrm{min})$

\begin{tabular}{cccccccc}
\hline Column & $\begin{array}{c}\text { Velocity } \\
(\mathrm{cm} / \mathrm{min})\end{array}$ & $\begin{array}{c}\mathrm{MTZ}_{0.1 \%} \\
(\mathrm{~cm})\end{array}$ & $\begin{array}{c}\text { Column } \\
\text { Length } \\
(\mathrm{cm})\end{array}$ & $\begin{array}{c}\text { Column } \\
\text { Volume } \\
(\mathrm{mL})\end{array}$ & $\begin{array}{c}\text { Sorbent } \\
\text { Weight } \\
(\mathrm{g})\end{array}$ & $\Delta \mathrm{P}(\mathrm{atm})$ & $\begin{array}{c}\text { Mo-99/Sorbent } \\
\text { Mass (Ci/g) }\end{array}$ \\
\hline & & & & & & & \\
12 & 18.99 & 12.28 & 13 & 1470 & 1911 & 0.38 & 2.26 \\
15 & 12.15 & 7.93 & 9 & 1590 & 2068 & 0.17 & 2.09 \\
20 & 6.84 & 4.53 & 5 & 1571 & 2042 & 0.05 & 2.11 \\
30 & 3.04 & 2.13 & 3 & 2121 & 2757 & 0.01 & 1.56 \\
\hline
\end{tabular}

TABLE 6 Preliminary Designs for Recovery of Mo from $262 \mathrm{~L}$ of $130 \mathrm{~g}-\mathrm{U} / \mathrm{L}$, $2.10 \times 10^{-3} \mathrm{mM} \mathrm{Mo}$, at $80^{\circ} \mathrm{C}(\mathrm{S110}, 99.9 \%$ recovery, 2-hour loading time, $2.2 \mathrm{~L} / \mathrm{min})$

\begin{tabular}{cccccccc}
\hline Column & $\begin{array}{c}\text { Velocity } \\
(\mathrm{cm} / \mathrm{min})\end{array}$ & $\begin{array}{c}\mathrm{MTZ}_{0.1 \%} \\
(\mathrm{~cm})\end{array}$ & $\begin{array}{c}\text { Column } \\
\text { Length } \\
(\mathrm{cm})\end{array}$ & $\begin{array}{c}\text { Column } \\
\text { Volume } \\
(\mathrm{L})\end{array}$ & $\begin{array}{c}\text { Sorbent } \\
\text { Weight } \\
(\mathrm{kg})\end{array}$ & $\Delta \mathrm{P}(\mathrm{atm})$ & $\begin{array}{c}\text { Mo-99/Sorbent } \\
\text { Mass (Ci/g) }\end{array}$ \\
\hline & & & & & & & \\
10 & 27.82 & 17.36 & 20 & 1.6 & 2.04 & 0.63 & 1.90 \\
12 & 19.32 & 12.04 & 14 & 1.6 & 2.06 & 0.30 & 1.89 \\
15 & 12.37 & 7.80 & 9 & 1.6 & 2.07 & 0.13 & 1.88 \\
20 & 6.96 & 4.43 & 5 & 1.6 & 2.04 & 0.04 & 1.90 \\
\hline
\end{tabular}

TABLE 7 Preliminary Designs for Recovery of Mo from 178.3 $\mathrm{L}$ of $124.8 \mathrm{~g}-\mathrm{U} / \mathrm{L}$, $2.98 \times 10^{-3} \mathrm{mM} \mathrm{Mo}$, at $60^{\circ} \mathrm{C}(\mathrm{S110}, 99.9 \%$ recovery, 2 -hour loading time, $1.5 \mathrm{~L} / \mathrm{min})$

\begin{tabular}{cccccccc}
\hline Column & $\begin{array}{c}\text { Velocity } \\
(\mathrm{cm} / \mathrm{min})\end{array}$ & $\begin{array}{c}\mathrm{MTZ}_{0.1 \%} \\
(\mathrm{~cm})\end{array}$ & $\begin{array}{c}\text { Column } \\
\text { Length } \\
(\mathrm{cm})\end{array}$ & $\begin{array}{c}\text { Column } \\
\text { Volume } \\
(\mathrm{mL})\end{array}$ & $\begin{array}{c}\text { Sorbent } \\
\text { Weight } \\
(\mathrm{g})\end{array}$ & $\Delta \mathrm{P}(\mathrm{atm})$ & $\begin{array}{c}\text { Mo-99/Sorbent } \\
\text { Mass (Ci/g) }\end{array}$ \\
\hline & & & & & & & \\
10 & 18.92 & 15.66 & 17 & 1335 & 1736 & 0.53 & 2.18 \\
15 & 8.41 & 7.07 & 8 & 1414 & 1838 & 0.11 & 2.05 \\
20 & 4.73 & 4.06 & 5 & 1571 & 2042 & 0.04 & 1.85 \\
25 & 3.03 & 2.67 & 3.5 & 1718 & 2233 & 0.02 & 1.69 \\
\hline
\end{tabular}


TABLE 8 Preliminary Designs for Recovery of Mo from $142.3 \mathrm{~L}$ of $146.8 \mathrm{~g}-\mathrm{U} / \mathrm{L}$, $3.55 \times 10^{-3} \mathrm{mM} \mathrm{Mo}$, at $60^{\circ} \mathrm{C}(\mathrm{S110}, 99.9 \%$ recovery, 2 -hour loading time, $1.2 \mathrm{~L} / \mathrm{min})$

\begin{tabular}{cccccccc}
\hline Column & $\begin{array}{c}\text { Velocity } \\
(\mathrm{cm} / \mathrm{min})\end{array}$ & $\begin{array}{c}\text { MTZ }_{0.1 \%} \\
(\mathrm{~cm})\end{array}$ & $\begin{array}{c}\text { Column } \\
\text { Length } \\
(\mathrm{cm})\end{array}$ & $\begin{array}{c}\text { Column } \\
\text { Volume } \\
(\mathrm{mL})\end{array}$ & $\begin{array}{c}\text { Sorbent } \\
\text { Weight } \\
(\mathrm{g})\end{array}$ & $\begin{array}{c}\Delta \mathrm{P} \\
(\mathrm{atm})\end{array}$ & $\begin{array}{c}\text { Mo-99/Sorbent } \\
\text { Mass (Ci/g) }\end{array}$ \\
\hline $\mathrm{ID}(\mathrm{cm})$ & & & & & & & \\
10 & 15.1 & 12.97 & 14 & 1100 & 1429 & 0.37 & 2.51 \\
12 & 10.49 & 9.07 & 10 & 1131 & 1470 & 0.18 & 2.44 \\
15 & 6.71 & 5.87 & 7 & 1237 & 1608 & 0.08 & 2.23 \\
20 & 3.77 & 3.39 & 4 & 1257 & 1634 & 0.03 & 2.20 \\
\hline
\end{tabular}

Despite the fact the sorbent utilization for the different configurations can be increased by $28-32 \%$ by increasing the loading time from 2 to 4 hours, and by $42-44 \%$ by increasing the loading time from 2 to 6 hours, it was decided saving time was more important than using less sorbent. The optimal column designs being considered and tested on a laboratory scale focus on a loading time of 2 hours. Another way to increase sorbent utilization is to decrease Mo recovery from $99.9 \%$ to $99 \%$ in VERSE, but that option is not being pursued. From a separation and recovery standpoint, the optimal configuration should have the highest Mo concentration and lowest feed volume. The target solution configuration that looks most promising is the $146.8 \mathrm{~g}-\mathrm{U} / \mathrm{L}$ design because it has the best sorbent utilization and smallest column sizes. Lowering the column volume has at least two benefits: (1) decreasing the volume and mass of the spent column material in the waste, and (2) lowering the volumes of the column wash streams and the Mo-product stream.

Under the conditions modeled in this study, the calculated mass transfer area is nearly proportional to the inverse of the linear velocity. Therefore, as long as the volume is kept constant, the geometry of the column is not a key factor. The column geometry should be sized for easy, reliable packing, to maintain the relatively low pressure drop in the column, and to accommodate other economic and operational factors.

Based on having the column pressure drop below $0.5 \mathrm{~atm}$ and having a column geometry that can be easily and reliably packed, the following column dimensions are suggested:

- For recovery of Mo in 2 hours, the recommended column is $10 \times 14 \mathrm{~cm}$ $(\mathrm{ID} \times \mathrm{L})$ utilizing approximately $1.4 \mathrm{~kg}$ of sorbent with a $\Delta \mathrm{P} 0.37 \mathrm{~atm}$. The projected acid wash volume for this design is $5.5 \mathrm{~L}$, projected water wash is 5.5 L, and projected Mo-product volume is $22-33 \mathrm{~L}$.

\subsection{DOWNSCALE COLUMN EXPERIMENTS}

Several laboratory-scale column experiments were performed in an effort to test the VERSE plant-scale column designs. The column sizes that were tested were chosen based on the availability of the columns and the amount of feed volume. Results from 1-4 downscale 
experiments are shown for each of the different target solution configurations being considered by SHINE in Table 9. All column experiments were done using a depleted uranium solution as uranyl sulfate ( $\mathrm{pH}$ 1), with stable Mo at the specified concentration added as sodium molybdate and tracer Mo-99.

The feed solution was heated to 60 or $80^{\circ} \mathrm{C}$ prior to being loaded onto the column. The column was kept at 60 or $80^{\circ} \mathrm{C}$ using heat tape, and stainless steel coils wrapped in heat tape were placed immediately before and after the column inlet and outlet to ensure the temperature of the solution entering the column was maintained at 60 or $80^{\circ} \mathrm{C}$. The strip solution was heated to $70^{\circ} \mathrm{C}$ to achieve optimal Mo recovery because lower Mo recoveries were observed when the strip solution was kept at room temperature or heated to temperatures $\geq 80^{\circ} \mathrm{C}$. Each column experiment was performed as follows:

1. Column was equilibrated with 10 column volumes (CVs) of $0.1-\mathrm{M} \mathrm{H}_{2} \mathrm{SO}_{4}$.

2. Feed solution (heated to the appropriate temperature) was loaded onto the column at a specific linear velocity in the upflow direction (to concentrate Mo on the bottom of the column and prevent entrapment of fission gases for future column runs with irradiated solutions).

3. Column was washed with $5 \mathrm{CVs}$ of $1-\mathrm{M} \mathrm{H}_{2} \mathrm{SO}_{4}$ in the upflow direction (to ensure any adsorbed $\mathrm{Pu}$ is removed from the column for future runs with irradiated solutions).

TABLE 9 Results for the Downscale Column Experiments for the Five Different Target Solution Configurations

\begin{tabular}{|c|c|c|c|c|c|c|c|c|c|}
\hline $\begin{array}{c}\mathrm{U} \\
\text { Concentration } \\
(\mathrm{g}-\mathrm{U} / \mathrm{L}) \\
\end{array}$ & $\begin{array}{c}\text { Mo } \\
\text { Concentration } \\
(\mathrm{mM}) \\
\end{array}$ & $\begin{array}{c}\text { Feed } \\
\text { Volume } \\
(\mathrm{mL})\end{array}$ & $\begin{array}{l}\text { Column } \\
\text { ID }(\mathrm{cm})\end{array}$ & $\begin{array}{c}\text { Column } \\
\mathrm{L}(\mathrm{cm})\end{array}$ & $\begin{array}{c}\% \text { Mo } \\
\text { Effluent }\end{array}$ & $\begin{array}{c}\% \text { Mo } \\
\text { Recovered }\end{array}$ & $\begin{array}{l}\text { Loading } \\
\text { Velocity } \\
(\mathrm{cm} / \mathrm{min}) \\
\end{array}$ & $\begin{array}{l}\text { Stripping } \\
\text { Velocity } \\
(\mathrm{cm} / \mathrm{min}) \\
\end{array}$ & $\begin{array}{c}\text { Feed } \\
\text { Temperature } \\
\left({ }^{\circ} \mathrm{C}\right)\end{array}$ \\
\hline 90 & $1.73 \times 10^{-3}$ & 441 & 1 & 8 & 0.3 & $82^{\mathrm{a}}$ & 5 & 5 & 60 \\
\hline 90 & $1.73 \times 10^{-3}$ & 288 & 1 & 5 & 1.0 & 90 & 3 & 3 & 60 \\
\hline 90 & $1.73 \times 10^{-3}$ & 372 & 1 & 5 & 0.7 & 100 & 4 & 4 & 60 \\
\hline 90 & $1.73 \times 10^{-3}$ & 468 & 1 & 5 & 1.1 & 94 & 5 & 5 & 60 \\
\hline 104 & $2.35 \times 10^{-3}$ & 504 & 1 & 3 & 0.2 & 96 & 3.1 & 1.6 & 60 \\
\hline 125 & $2.98 \times 10^{-3}$ & 196 & 0.66 & 5 & 0.1 & 100 & 4.7 & 2.3 & 60 \\
\hline 130 & $2.10 \times 10^{-3}$ & 665 & 1 & 5 & 0.08 & 100 & 7 & 3.5 & 80 \\
\hline 130 & $2.10 \times 10^{-3}$ & 665 & 1 & 5 & 0.11 & 86 & 7 & 7 & 80 \\
\hline 130 & $2.10 \times 10^{-3}$ & 665 & 1 & 5 & 0.33 & $81^{\mathrm{b}}$ & 7 & 3.5 & 80 \\
\hline 146 & $3.55 \times 10^{-3}$ & 364 & 1 & 4 & 0.66 & 92 & 3.8 & 1.9 & 60 \\
\hline 146 & $3.55 \times 10^{-3}$ & 364 & 1 & 4 & 0.1 & 66 & 3.8 & 3.8 & 60 \\
\hline
\end{tabular}


4. Column was washed with $5 \mathrm{CVs}$ of $\mathrm{H}_{2} \mathrm{O}$ in the upflow direction (to remove any acid).

5. Mo was eluted by passing $30 \mathrm{CVs}$ of $1-\mathrm{M} \mathrm{NH}_{4} \mathrm{OH}$ heated to $70^{\circ} \mathrm{C}$ through the column in the downflow direction.

6. Column was washed with $5 \mathrm{CVs}$ of $\mathrm{H}_{2} \mathrm{O}$ in the upflow direction. A freshly packed titania column was used for each experiment.

The plant-scale column designs generated using VERSE assume 99.9\% Mo will be adsorbed and recovered. Direct downscale column experiments show that $0.1-1.1 \pm 5 \%$ (of the $0.1-1.1 \%$ ) Mo is found in the effluent. Due to the error associated with the gamma counting results, $1 \%$ or less Mo in the effluent shows good Mo adsorption and effective column design.

Mo recoveries ranged from 66 to $100 \pm 5 \%$ for the downscale column experiments. Results from the downscale column experiments suggest that the stripping velocity should be half of the loading velocity to achieve 90-100 $\pm 5 \%$ recovery of Mo. For example, only $66 \%$ Mo was recovered when the loading and strip velocities were the same for the $146 \mathrm{~g}-\mathrm{U} / \mathrm{L}$ experiment; however, $92 \%$ Mo was recovered when the linear velocity for the strip solution was decreased from 3.8 to $1.9 \mathrm{~cm} / \mathrm{min}$. In addition, the temperature of the strip solution should be maintained at $70^{\circ} \mathrm{C}$ to ensure diffusion into the sorbent pores and release of Mo. For example, $82 \%$ Mo was recovered for the $90 \mathrm{~g}-\mathrm{U} / \mathrm{L}$ experiment when the strip solution was not heated, and $81 \%$ Mo was recovered for the $130 \mathrm{~g}-\mathrm{U} / \mathrm{L}$ experiment when the strip solution was heated to $80^{\circ} \mathrm{C}$ (100\% Mo was recovered under the same conditions for the $130 \mathrm{~g}-\mathrm{U} / \mathrm{L}$ experiment when the strip solution was heated to $70^{\circ} \mathrm{C}$ ). When the temperature of the strip solution exceeds approximately $70^{\circ} \mathrm{C}$, a significant number of bubbles form and are subsequently passed through the column, decreasing the amount of Mo recovered.

For the plant-scale operation, recovering approximately $80-85 \%$ of the Mo actually formed after purification will be viewed as a success. Since the expected Mo yield for the LEU-Modified Cintichem purification process is between 85 and $90 \%$, the recovery operation must recover $95 \%$ of the Mo. The column experiments completed thus far have not studied the effects of other fission and activation products on Mo adsorption and recovery or the effects of a high radiation field on Mo redox chemistry. The mini-SHINE experiments will examine the effects of potential competing components on Mo adsorption and recovery because approximately $2 \mathrm{Ci}$ Mo-99 and all other fission products will be produced by irradiating $5 \mathrm{~L}$ of a uranyl sulfate solution at the linac. In addition, the effect of a high radiation field on Mo redox chemistry will be studied in the mini-SHINE experiments, because if less Mo is adsorbed or recovered on the titania column than what is expected, a portion of Mo(VI) may have been reduced to $\mathrm{Mo}(\mathrm{IV})$ or $\mathrm{Mo}(\mathrm{V})$. If this is the case, an oxidizing agent such as potassium permanganate will be used to ensure Mo is present as Mo(VI). 


\subsection{DENSITY RESULTS}

A Mettler-Toledo density meter was used for all density measurements. It is equipped with a hollow glass tube that vibrates at a certain frequency, and when a solution enters the tube, the frequency changes. As the mass increases, the frequency decreases, and the new frequency can be used to determine the density of the solution at the specified temperature. The densities of uranyl sulfate solutions with concentrations ranging from approximately 90 to $140 \mathrm{~g}-\mathrm{U} / \mathrm{L}$ and temperatures from 20 to $80^{\circ} \mathrm{C}$ were determined. The values are shown in Table 10 . The results are reasonable because for all samples the density decreases as the temperature increases. Errors of \pm 0.02 to $0.05 \mathrm{~g} / \mathrm{mL}$ mean that using density as a means to measure uranium concentration is not accurate enough for SHINE.

Density values for uranyl sulfate solutions at $60^{\circ} \mathrm{C}$ were required for VERSE simulations to design a column for the SHINE process. Literature data were used to generate a line to calculate the densities of different uranyl sulfate solutions being considered by SHINE at $60^{\circ} \mathrm{C}$ (current target solution temperature is now $80^{\circ} \mathrm{C}$ ). Table 11 shows a comparison between measured and calculated densities for uranyl sulfate solutions at $60^{\circ} \mathrm{C}$, with $\mathrm{pH} 1$. The differences between the calculated and measured density values are lower than the errors associated with the measurements alone, which confirms that the calculated values initially used in the VERSE simulations were reliable.

\subsection{PH MEASUREMENTS}

The $\mathrm{pH}$ measurements were completed using an Orion Ultra $\mathrm{pH}$ electrode and meter. The effect of temperature on the $\mathrm{pH}$ of the $\mathrm{pH} 1$ buffer was more significant than anticipated. As a result, adjustments to the $\mathrm{pH}$ values of the uranyl sulfate solutions were made. The typical $\mathrm{pH}$ changes observed for a $\mathrm{pH} 1$ buffer as a function of temperature are shown in Table 12.

TABLE 10 Density Values Measured for Uranyl Sulfate Solutions

\begin{tabular}{cccccccc}
\hline & \multicolumn{7}{c}{ Density $(\mathrm{g} / \mathrm{mL})$} \\
\cline { 2 - 8 } $\begin{array}{c}\text { Sample } \\
(\mathrm{g}-\mathrm{U} / \mathrm{L})\end{array}$ & $20^{\circ} \mathrm{C}$ & $30^{\circ} \mathrm{C}$ & $40^{\circ} \mathrm{C}$ & $50^{\circ} \mathrm{C}$ & $60^{\circ} \mathrm{C}$ & $70^{\circ} \mathrm{C}$ & $80^{\circ} \mathrm{C}$ \\
\hline & & & & & & & \\
88 & 1.128 & 1.123 & 1.119 & 1.112 & 1.104 & 1.094 & 1.092 \\
103 & 1.154 & 1.150 & 1.145 & 1.140 & 1.134 & 1.128 & 1.122 \\
117 & 1.172 & 1.168 & 1.163 & 1.158 & 1.152 & 1.146 & 1.139 \\
128 & 1.182 & 1.178 & 1.173 & 1.168 & 1.161 & 1.155 & 1.149 \\
130 & 1.193 & 1.189 & 1.184 & 1.178 & 1.171 & 1.164 & 1.160 \\
138 & 1.199 & 1.195 & 1.191 & 1.185 & 1.179 & 1.173 & 1.166 \\
\hline
\end{tabular}




\section{TABLE 11 Calculated and Measured Density Values}

\begin{tabular}{ccc}
\hline $\begin{array}{c}\text { Uranium } \\
\begin{array}{c}\text { Concentration } \\
(\mathrm{g}-\mathrm{U} / \mathrm{L})\end{array}\end{array}$ & $\begin{array}{c}\text { Calculated } \rho \\
(\mathrm{g} / \mathrm{mL})\end{array}$ & $\begin{array}{c}\text { Measured } \rho \\
(\mathrm{g} / \mathrm{mL})\end{array}$ \\
\hline 88 & 1.10 & 1.10 \\
103 & 1.12 & 1.13 \\
128 & 1.15 & 1.16 \\
138 & 1.17 & 1.18 \\
\hline
\end{tabular}

TABLE 12 pH Values Measured for $\mathrm{pH} 1$ Buffer as a Function of Temperature

\begin{tabular}{cc}
\hline & \\
Temperature $\left({ }^{\circ} \mathrm{C}\right)$ & $\mathrm{pH}$ \\
\hline 25.2 & 1.01 \\
30.1 & 0.99 \\
40.2 & 1.03 \\
50.0 & 1.05 \\
59.9 & 1.08 \\
70.2 & 1.11 \\
80.1 & 1.17 \\
\hline
\end{tabular}

The overall trend showed that the $\mathrm{pH}$ of the uranyl sulfate solutions increased as the temperature increased. This contradicts previous literature data that showed that the $\mathrm{pH}$ of a uranyl sulfate solution decreases as the temperature increases (Orban et al. 1956). However, the dissociation of $\mathrm{HSO}_{4}{ }^{-}$decreases with increasing temperature, which lessens the amount of free $\mathrm{H}^{+}$in solution (Knopf 2003). All solutions contain an excess of sulfuric acid to keep the $\mathrm{pH}$ at 1 , and the excess $\mathrm{HSO}_{4}{ }^{-}$most likely accounts for the decreased $\mathrm{pH}$ values observed at higher temperatures. Figure 4 shows a plot of $\mathrm{pH}$ versus temperature for uranyl sulfate solutions containing approximately 80-140 g-U/L, room temperature $\mathrm{pH}$ between 1 and 1.3 , and temperatures from approximately 22 to $80^{\circ} \mathrm{C}$. A more detailed table of the $\mathrm{pH}$ results is given in Appendix B.

\subsection{VISCOSITY MEASUREMENTS}

Viscosity measurements were completed using a Cambridge viscometer. Approximately $2 \mathrm{~mL}$ of a solution is placed in a thermostated sample holder, and a small magnetic piston is inserted into the holder. The piston is surrounded by liquid sample, and it moves up and down a 


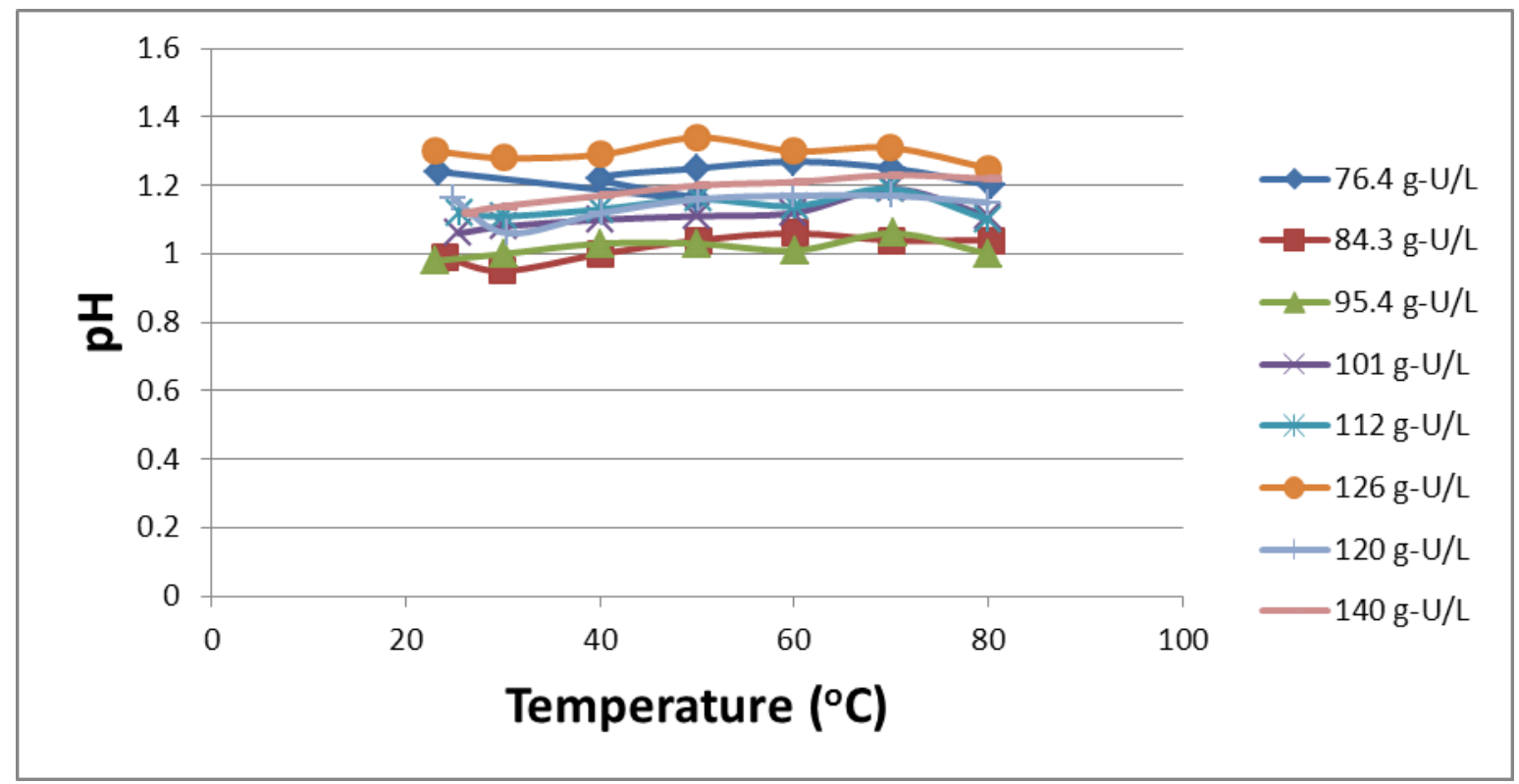

\section{FIGURE 4 A Plot of pH Versus Temperature for Uranyl Sulfate Solutions}

distance of $0.2 \mathrm{in}$. inside the sample cell through the use of magnetic coils. The time required to make the two-way cycle can be used to determine the viscosity of the solution at a specific temperature.

Results are shown in Figure 5, but it is worth noting that the values obtained at higher temperatures $\left(70-80^{\circ} \mathrm{C}\right.$ ) are not as accurate as the values obtained at lower temperatures. This is because the system is closed, but does not have a condenser. As a result, condensation formed on top of the sample holder. The value obtained for the viscosity was heavily dependent on the amount of time required to complete the measurement. For the measurements between 70 and $80^{\circ} \mathrm{C}$, an average of three separate measurements were taken, but the error associated with these measurements is still about $2 \%$. A detailed table of the viscosity results is shown in Appendix C.

Viscosity values for uranyl sulfate solutions at $60^{\circ} \mathrm{C}$ were required for VERSE simulations to design a column for the SHINE process. Literature data were used to generate a line to calculate the viscosities of different uranyl sulfate solutions being considered by SHINE at $60^{\circ} \mathrm{C}$ (current target solution temperature is now $80^{\circ} \mathrm{C}$ ). Table 13 shows a comparison between measured and calculated viscosities for uranyl sulfate solutions at $60^{\circ} \mathrm{C}$, with $\mathrm{pH} 1$. The differences between the calculated and measured viscosity values are within $0.04 \mathrm{Cp}$, which confirms that the calculated values initially used in the VERSE simulations were reliable.

\subsection{THERMAL CONDUCTIVITY AND SPECIFIC HEAT MEASUREMENTS}

The Thermtest thermal conductivity meter measures thermal conductivity, thermal diffusivity, and specific heat if the density of the solution is known. A thin platinum wire 


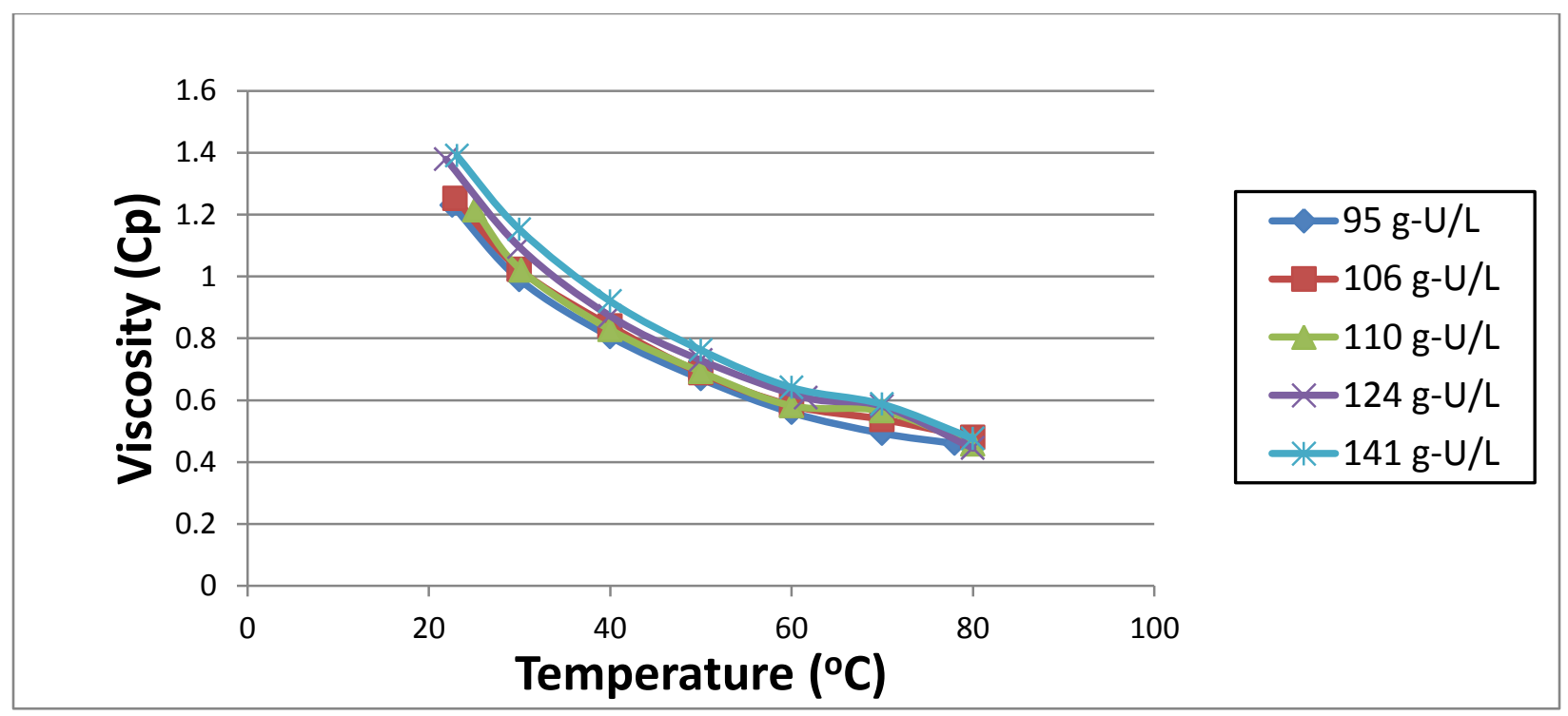

FIGURE 5 A Plot of Viscosity Versus Temperature for Uranyl Sulfate Solutions

TABLE 13 Calculated and Measured Viscosity Values

\begin{tabular}{ccc}
\hline $\begin{array}{c}\text { Uranium } \\
\text { Concentration } \\
(\mathrm{g}-\mathrm{U} / \mathrm{L})\end{array}$ & $\begin{array}{c}\text { Calculated } \\
\mu(\mathrm{Cp})\end{array}$ & $\begin{array}{c}\text { Measured } \\
\mu(\mathrm{Cp})\end{array}$ \\
\hline & & \\
95 & 0.59 & 0.56 \\
106 & 0.61 & 0.58 \\
110 & 0.62 & 0.58 \\
124 & 0.64 & 0.61 \\
141 & 0.67 & 0.64 \\
\hline
\end{tabular}

attached to a sensor and thermocouple is inserted in a cylinder containing about $50 \mathrm{~mL}$ of solution. A current is sent through the wire to heat the solution, and the resistance of the wire is measured with respect to time. A temperature-time profile is generated that can be used to determine the thermal properties of the solution. Unfortunately, the thermal conductivity sensor corroded in the presence of $\mathrm{pH} 1$ sulfuric acid. The manufacturer suggested coating the soldering joints with silicone caulk to prevent corrosion in the future. After doing this, a reliable calibration curve could not be generated. As a result, the manufacturer is making a custom sensor for us that is resistant to corrosion in acidic media. The sensor will not be available for at least 2-4 weeks. As soon as the new sensor has been received, the measurements will be made for thermal conductivity and specific heat of uranyl sulfate solutions containing 90-140 g-U/L with temperatures ranging from 20 to $80^{\circ} \mathrm{C}$. 


\section{CONCLUSIONS AND FUTURE WORK}

Several column designs have been generated for the SHINE target solution configurations, and downscale column designs have been tested using non-irradiated uranyl sulfate solutions with stable Mo and tracer Mo-99. Overall, the direct downscale experiments show that any of the five potential target solution configurations can be used to design a column with the parameters needed for good Mo adsorption and recovery. Two important factors were identified during the downscale column experiments to increase Mo recovery: (1) decreasing the stripping velocity by $50 \%$ compared to the loading velocity and (2) heating the strip solution to $70^{\circ} \mathrm{C}$. Both factors will be implemented for the plant-scale operation.

Three parameters have been discussed that affect column efficiency: Mo concentration, uranium concentration, and feed flow rate. From a Mo-recovery perspective, target-solution designs with the highest power density (and thus the highest Mo concentrations), even with higher uranium concentrations, will require columns with the lowest volumes. For example, the plant-scale column designs for the $146.8 \mathrm{~g}-\mathrm{U} / \mathrm{L}$ uranyl sulfate target solution configuration with a Mo concentration of $3.55 \times 10^{-3} \mathrm{mM}$ are the most efficient. For the recovery of Mo in 2 hours, the recommended column is $10 \mathrm{~cm} \times 14 \mathrm{~cm}(\mathrm{ID} \times \mathrm{L})$ using approximately $1.4 \mathrm{~kg}$ of sorbent with a pressure drop of $0.37 \mathrm{~atm}$. The projected acid wash volume for this design is $5.5 \mathrm{~L}$, projected water wash is $5.5 \mathrm{~L}$, and projected Mo-product volume is between 22 and $33 \mathrm{~L}$. For any of the other potential target solution configurations, the plant-scale column designs (2-hour loading) with internal diameters of 10-12 $\mathrm{cm}$ are the best options because they are the smallest columns and will minimize wash and waste volumes. Increasing the loading time was also discussed to increase overall column efficiency, but it is not being implemented at this point.

Modifications to the current plant-scale column designs will most likely occur after results from the mini-SHINE experiments have been obtained. The effect of potential competing components on Mo adsorption and recovery may increase the column sizes slightly; however, the length of the mass-transfer zone has already been increased by $10 \%$ to account for system problems. As a result, increasing the column size may not be necessary. In addition, an oxidizing agent may need to be added to one or more steps during the plant-scale operation to ensure Mo is present as $\mathrm{Mo}(\mathrm{VI})$.

Once the final SHINE target solution configuration has been determined, Langmuir data will be obtained using the proper uranium concentration and temperature. In addition, if modifications are needed based on results from the mini-SHINE experiments, those will be implemented as well.

Density, $\mathrm{pH}$, and viscosity measurements have been made for potential SHINE target solutions containing between 90 and $140 \mathrm{~g}-\mathrm{U} / \mathrm{L}$ uranyl sulfate at temperatures between 20 and $80^{\circ} \mathrm{C}$. The density and viscosity results follow what was expected where both parameters decrease with increasing temperature. Density and/or viscosity values can be used to generate an estimate of uranium concentration $( \pm 5-10 \%)$ but cannot be used as a means to determine the concentration within $1 \%$ or less. The $\mathrm{pH}$ actually increased as temperature increased, which contradicts a previous literature report (Orban et al. 1956). A feasible explanation is the fact that 
there is an excess of sulfate in solution, and bisulfate dissociation decreases with increasing concentration, resulting in less free $\mathrm{H}^{+}$in solution (Knopf 2003). The thermal conductivity and specific heat measurements will be completed once the new sensor that is compatible with acidic solutions arrives at Argonne. 


\section{REFERENCES}

Chung, S.F., and C.Y. Wen, 1968, "Longitudinal Dispersion of Liquid Flowing through Fixed and Fluidized Beds," American Institute of Chemical Engineers Journal 14: 857-866.

Knopf, D.A., 2003, “Thermodynamic Dissociation Constant of the Bisulfate Ion from Raman and Ion Interaction Modeling Studies of Aqueous Sulfuric Acid at Low Temperatures," J. Phys. Chem. A. 107: 4322-4332.

Langmuir, I., 1916, "The Constitution and Fundamental Properties of Solids and Liquids. Part I Solids," Journal of the American Chemical Society, 38: 2221-2295.

Marcus, Y., 1997, Ion Properties, Marcel Dekker, Inc., New York, New York.

McDuffie, H.F., 1960, "Properties of Aqueous Fuel Solutions," Aqueous Homogeneous Reactors, Chapter 3. J.E. Lane (editor).

Orban, E., K.B. Martin, J.S. Boyle, J.R. Heiks, and L.V. Jones, 1956, "Physical Properties of Aqueous Uranyl Sulfate Solutions from 20 to 90," J. Phys. Chem. 60: 413-415.

Rhodes, F.H., and C.B. Barbour, 1923, "The Viscosities of Mixtures of Sulfuric Acid and Water," Ind. Eng. Chem. 15: 850.

Wilson, E.J., and C. Geankoplis, 1966, "Liquid Mass Transfer at Very Low Reynolds Numbers in Packed Beds," Industrial \& Engineering Chemistry Fundamentals 5(1): 9-14.

Xu, T., and K. Pruess, 2001, "On Fluid Flow and Mineral Alteration in Fractured Caprock of Magmatic Hydrothermal Systems," Journal of Geophysical Research 106(B2). DOI:

10.1029/2000JB900356. 


\section{APPENDIX A:}

\section{PLANT-SCALE COLUMN DESIGNS FOR THE POTENTIAL SHINE TARGET SOLUTION CONFIGURATIONS WITH LOADING TIMES OF 4 AND 6 HOURS}

TABLE A-1 Preliminary Designs for Recovery of Mo from $395 \mathrm{~L}$ of $90 \mathrm{~g}-\mathrm{U} / \mathrm{L}$, $1.78 \times 10^{-3} \mathrm{mM} \mathrm{Mo}$, at $60^{\circ} \mathrm{C}(\mathrm{S110}, 99.9 \%$ recovery, 4-hour loading time, $1.7 \mathrm{~L} / \mathrm{min})$

\begin{tabular}{cccccccc}
\hline Column & $\begin{array}{c}\text { Velocity } \\
(\mathrm{cm} / \mathrm{min})\end{array}$ & $\begin{array}{c}\mathrm{MTZ}_{0.1 \%} \\
(\mathrm{~cm})\end{array}$ & $\begin{array}{c}\text { Column } \\
\text { Length } \\
(\mathrm{cm})\end{array}$ & $\begin{array}{c}\text { Column } \\
\text { Volume } \\
(\mathrm{mL})\end{array}$ & $\begin{array}{c}\text { Sorbent } \\
\text { Weight } \\
(\mathrm{g})\end{array}$ & $\begin{array}{c}\Delta \mathrm{P} \\
(\mathrm{atm})\end{array}$ & $\begin{array}{c}\text { Mo-99/Sorbent } \\
\text { Mass (Ci/g) }\end{array}$ \\
\hline 10 & 20.96 & 18.07 & 19 & 1492 & 1940 & 0.6 & 2.58 \\
12 & 14.55 & 12.64 & 14 & 1583 & 2058 & 0.31 & 2.43 \\
15 & 9.31 & 8.19 & 9 & 1590 & 2068 & 0.13 & 2.42 \\
20 & 5.24 & 4.73 & 6 & 1885 & 2450 & 0.05 & 2.04 \\
25 & 3.35 & 3.13 & 4 & 1963 & 2553 & 0.02 & 1.96 \\
\hline
\end{tabular}

TABLE A-2 Preliminary Designs for Recovery of Mo from $395 \mathrm{~L}$ of $90 \mathrm{~g}-\mathrm{U} / \mathrm{L}$, $1.78 \times 10^{-3} \mathrm{mM} \mathrm{Mo}$, at $60^{\circ} \mathrm{C}(\mathrm{S110}, 99.9 \%$ recovery, 6-hour loading time, $1.1 \mathrm{~L} / \mathrm{min})$

\begin{tabular}{cccccccc}
\hline Column & $\begin{array}{c}\text { Velocity } \\
(\mathrm{cm} / \mathrm{min})\end{array}$ & $\begin{array}{c}\mathrm{MTZ}_{0.1 \%} \\
(\mathrm{~cm})\end{array}$ & $\begin{array}{c}\text { Column } \\
\text { Length } \\
(\mathrm{cm})\end{array}$ & $\begin{array}{c}\text { Column } \\
\text { Volume } \\
(\mathrm{mL})\end{array}$ & $\begin{array}{c}\text { Sorbent } \\
\text { Weight } \\
(\mathrm{g})\end{array}$ & $\begin{array}{c}\Delta \mathrm{P} \\
(\mathrm{atm})\end{array}$ & $\begin{array}{c}\text { Mo-99/Sorbent } \\
\text { Mass (Ci/g) }\end{array}$ \\
\hline 10 & 13.97 & 14.88 & 16 & 1257 & 1634 & 0.34 & 3.06 \\
12 & 9.7 & 10.42 & 12 & 1357 & 1764 & 0.17 & 2.83 \\
15 & 6.21 & 6.77 & 8 & 1414 & 1838 & 0.07 & 2.72 \\
20 & 3.49 & 3.93 & 5 & 1571 & 2042 & 0.03 & 2.45 \\
\hline
\end{tabular}

TABLE A-3 Preliminary Designs for Recovery of Mo from 257.7 L of 104.2 g-U/L, $2.35 \times 10^{-3} \mathrm{mM} \mathrm{Mo}$, at $60^{\circ} \mathrm{C}(\mathrm{S110}, 99.9 \%$ recovery, 4-hour loading time, $1.1 \mathrm{~L} / \mathrm{min})$

\begin{tabular}{cccccccc}
\hline Column & $\begin{array}{c}\text { Velocity } \\
(\mathrm{cm} / \mathrm{min})\end{array}$ & $\begin{array}{c}\mathrm{MTZ}_{0.1 \%} \\
(\mathrm{~cm})\end{array}$ & $\begin{array}{c}\text { Column } \\
\text { Length } \\
(\mathrm{cm})\end{array}$ & $\begin{array}{c}\text { Column } \\
\text { Volume } \\
(\mathrm{mL})\end{array}$ & $\begin{array}{c}\text { Sorbent } \\
\text { Weight } \\
(\mathrm{g})\end{array}$ & $\begin{array}{c}\Delta \mathrm{P} \\
(\mathrm{atm})\end{array}$ & $\begin{array}{c}\text { Mo-99/Sorbent } \\
\text { Mass (Ci/g) }\end{array}$ \\
\hline 8 & 21.36 & 20 & 21 & 1056 & 1372 & 0.7 & 3.14 \\
10 & 13.67 & 12.7 & 14 & 1100 & 1429 & 0.3 & 3.02 \\
15 & 6.08 & 5.53 & 6.5 & 1149 & 1493 & 0.06 & 2.89 \\
20 & 3.42 & 3.19 & 4 & 1257 & 1634 & 0.02 & 2.64 \\
\hline
\end{tabular}


TABLE A-4 Preliminary Designs for Recovery of Mo from 257.7 L of 104.2 g-U/L, $2.35 \times 10^{-3} \mathrm{mM} \mathrm{Mo}$, at $60^{\circ} \mathrm{C}(\mathrm{S110}, 99.9 \%$ recovery, 6-hour loading time, $0.7 \mathrm{~L} / \mathrm{min})$

\begin{tabular}{cccccccc}
\hline Column & $\begin{array}{c}\text { Velocity } \\
(\mathrm{cm} / \mathrm{min})\end{array}$ & $\begin{array}{c}\mathrm{MTZ}_{0.1 \%} \\
(\mathrm{~cm})\end{array}$ & $\begin{array}{c}\text { Column } \\
\text { Length } \\
(\mathrm{cm})\end{array}$ & $\begin{array}{c}\text { Column } \\
\text { Volume } \\
(\mathrm{mL})\end{array}$ & $\begin{array}{c}\text { Sorbent } \\
\text { Weight } \\
(\mathrm{g})\end{array}$ & $\begin{array}{c}\Delta \mathrm{P} \\
(\mathrm{atm})\end{array}$ & $\begin{array}{c}\text { Mo-99/Sorbent } \\
\text { Mass (Ci/g) }\end{array}$ \\
\hline 8 & 14.24 & 15.6 & 17 & 855 & 1111 & 0.38 & 3.88 \\
10 & 9.11 & 10 & 11 & 864 & 1123 & 0.16 & 3.84 \\
15 & 4.05 & 4.6 & 5.5 & 972 & 1264 & 0.03 & 3.41 \\
20 & 2.28 & 2.67 & 3.5 & 1100 & 1429 & 0.01 & 3.02 \\
\hline
\end{tabular}

TABLE A-5 Preliminary Designs for Recovery of Mo from 178.3 L of 124.8 g-U/L, $2.98 \times 10^{-3} \mathrm{mM} \mathrm{Mo}$, at $60^{\circ} \mathrm{C}(\mathrm{S110}, 99.9 \%$ recovery, 4-hour loading time, $0.7 \mathrm{~L} / \mathrm{min})$

\begin{tabular}{cccccccc}
\hline Column & $\begin{array}{c}\text { Velocity } \\
(\mathrm{cm} / \mathrm{min})\end{array}$ & $\begin{array}{c}\mathrm{MTZ}_{0.1 \%} \\
(\mathrm{~cm})\end{array}$ & $\begin{array}{c}\text { Column } \\
\text { Length } \\
(\mathrm{cm})\end{array}$ & $\begin{array}{c}\text { Column } \\
\text { Volume } \\
(\mathrm{mL})\end{array}$ & $\begin{array}{c}\text { Sorbent } \\
\text { Weight } \\
(\mathrm{g})\end{array}$ & $\begin{array}{c}\Delta \mathrm{P} \\
(\mathrm{atm})\end{array}$ & $\begin{array}{c}\text { Mo-99/Sorbent } \\
\text { Mass (Ci/g) }\end{array}$ \\
\hline 8 & 14.78 & 17.27 & 18 & 905 & 1176 & 0.44 & 3.21 \\
10 & 9.46 & 11.17 & 12 & 942 & 1225 & 0.19 & 3.08 \\
12 & 6.57 & 7.8 & 9 & 1018 & 1323 & 0.1 & 2.85 \\
15 & 4.2 & 5.13 & 6 & 1060 & 1378 & 0.04 & 2.74 \\
\hline
\end{tabular}

TABLE A-6 Preliminary Designs for Recovery of Mo from $178.3 \mathrm{~L}$ of $124.8 \mathrm{~g}-\mathrm{U} / \mathrm{L}$, $2.98 \times 10^{-3} \mathrm{mM} M o$, at $60^{\circ} \mathrm{C}(\mathrm{S110}, 99.9 \%$ recovery, 6-hour loading time, $0.5 \mathrm{~L} / \mathrm{min})$

\begin{tabular}{|c|c|c|c|c|c|c|c|}
\hline $\begin{array}{l}\text { Column } \\
\text { ID }(\mathrm{cm})\end{array}$ & $\begin{array}{l}\text { Velocity } \\
(\mathrm{cm} / \mathrm{min}) \\
\end{array}$ & $\begin{array}{l}\mathrm{MTZ}_{0.1 \%} \\
\quad(\mathrm{~cm}) \\
\end{array}$ & $\begin{array}{c}\text { Column } \\
\text { Length } \\
(\mathrm{cm})\end{array}$ & $\begin{array}{c}\text { Column } \\
\text { Volume } \\
(\mathrm{mL})\end{array}$ & $\begin{array}{c}\text { Sorbent } \\
\text { Weight } \\
(\mathrm{g})\end{array}$ & $\begin{array}{c}\Delta \mathrm{P} \\
(\mathrm{atm})\end{array}$ & $\begin{array}{c}\text { Mo-99/Sorbent } \\
\text { Mass }(\mathrm{Ci} / \mathrm{g})\end{array}$ \\
\hline 6 & 17.52 & 25.34 & 26 & 735 & 956 & 0.75 & 3.95 \\
\hline 8 & 9.85 & 14.37 & 15 & 754 & 980 & 0.24 & 3.85 \\
\hline 10 & 6.31 & 9.27 & 10 & 785 & 1021 & 0.1 & 3.70 \\
\hline 15 & 2.8 & 4.27 & 5 & 884 & 1149 & 0.02 & 3.29 \\
\hline
\end{tabular}

TABLE A-7 Preliminary Designs for Recovery of Mo from $262 \mathrm{~L} \mathrm{of} 130 \mathrm{~g}-\mathrm{U} / \mathrm{L}$, $2.10 \times 10^{-3} \mathrm{mM} \mathrm{Mo}$, at $80^{\circ} \mathrm{C}(\mathrm{S110}, 99.9 \%$ recovery, 4-hour loading time, $1.1 \mathrm{~L} / \mathrm{min})$

\begin{tabular}{cccccccc}
\hline Column & $\begin{array}{c}\text { Velocity } \\
\text { Column }\end{array}$ & $\begin{array}{c}\text { Column } \\
\mathrm{MTZ}_{0.1 \%} \\
(\mathrm{~cm})\end{array}$ & $\begin{array}{c}\text { Length } \\
(\mathrm{cm})\end{array}$ & $\begin{array}{c}\text { Solume } \\
(\mathrm{L})\end{array}$ & $\begin{array}{c}\text { Weight } \\
(\mathrm{g})\end{array}$ & $\begin{array}{c}\Delta \mathrm{P} \\
(\mathrm{atm})\end{array}$ & $\begin{array}{c}\text { Mo-99/Sorbent } \\
\text { mass }(\mathrm{Ci} / \mathrm{g})\end{array}$ \\
\hline 8 & 21.74 & 19.16 & 22 & 1.1 & 1440 & 0.55 & 2.70 \\
10 & 13.91 & 12.4 & 14 & 1.1 & 1430 & 0.23 & 2.71 \\
12 & 9.66 & 8.8 & 10 & 1.1 & 1470 & 0.12 & 2.64 \\
15 & 6.18 & 5.8 & 7 & 1.1 & 1490 & 0.05 & 2.61 \\
\hline
\end{tabular}


TABLE A-8 Preliminary Designs for Recovery of Mo from $262 \mathrm{~L} \mathrm{of} 130 \mathrm{~g}-\mathrm{U} / \mathrm{L}$, $2.10 \times 10^{-3} \mathrm{mM} \mathrm{Mo}$, at $80^{\circ} \mathrm{C}(\mathrm{S110}, 99.9 \%$ recovery, 6-hour loading time, $0.7 \mathrm{~L} / \mathrm{min})$

\begin{tabular}{cccccccc}
\hline Column & $\begin{array}{c}\text { Velocity } \\
(\mathrm{cm} / \mathrm{min})\end{array}$ & $\begin{array}{c}\mathrm{MTZ}_{0.1 \%} \\
(\mathrm{~cm})\end{array}$ & $\begin{array}{c}\text { Column } \\
\text { Length } \\
(\mathrm{cm})\end{array}$ & $\begin{array}{c}\text { Column } \\
\text { Volume } \\
(\mathrm{L})\end{array}$ & $\begin{array}{c}\text { Sorbent } \\
\text { Weight } \\
(\mathrm{g})\end{array}$ & $\begin{array}{c}\Delta \mathrm{P} \\
(\operatorname{atm})\end{array}$ & $\begin{array}{c}\text { Mo-99/Sorbent } \\
\text { Mass (Ci/g) }\end{array}$ \\
\hline 6 & 25.76 & 28.32 & 31 & 0.9 & 1180 & 0.96 & 3.29 \\
8 & 14.49 & 16 & 18 & 0.9 & 1180 & 0.31 & 3.29 \\
10 & 9.27 & 10.4 & 12 & 0.9 & 1170 & 0.13 & 3.32 \\
12 & 6.44 & 7.2 & 8 & 0.9 & 1180 & 0.06 & 3.29 \\
15 & 4.12 & 4.71 & 6 & 0.97 & 1260 & 0.03 & 3.08 \\
\hline
\end{tabular}

TABLE A-9 Preliminary Designs for Recovery of Mo from 142.3 L of $146.8 \mathrm{~g}-\mathrm{U} / \mathrm{L}$, $3.55 \times 10^{-3} \mathrm{mM} \mathrm{Mo}$, at $60^{\circ} \mathrm{C}(\mathrm{S110}, 99.9 \%$ recovery, 4-hour loading time, $0.6 \mathrm{~L} / \mathrm{min})$

\begin{tabular}{cccccccc}
\hline Column & $\begin{array}{c}\text { Velocity } \\
(\mathrm{cm} / \mathrm{min})\end{array}$ & $\begin{array}{c}\mathrm{MTZ}_{0.1 \%} \\
(\mathrm{~cm})\end{array}$ & $\begin{array}{c}\text { Column } \\
\text { Length } \\
(\mathrm{cm})\end{array}$ & $\begin{array}{c}\text { Column } \\
\text { Volume } \\
(\mathrm{mL})\end{array}$ & $\begin{array}{c}\text { Sorbent } \\
\text { Weight } \\
(\mathrm{g})\end{array}$ & $\begin{array}{c}\Delta \mathrm{P} \\
(\mathrm{atm})\end{array}$ & $\begin{array}{c}\text { Mo-99/Sorbent } \\
\text { Mass (Ci/g) }\end{array}$ \\
\hline 6 & 20.97 & 25.21 & 26 & 735 & 956 & 0.95 & 3.75 \\
8 & 11.8 & 14.27 & 15 & 754 & 980 & 0.31 & 3.66 \\
10 & 7.55 & 9.19 & 10 & 785 & 1021 & 0.13 & 3.52 \\
15 & 3.36 & 4.2 & 5 & 884 & 1149 & 0.03 & 3.12 \\
\hline
\end{tabular}

TABLE A-10 Preliminary Designs for Recovery of Mo from 142.3 L of $146.8 \mathrm{~g}-\mathrm{U} / \mathrm{L}$, $3.55 \times 10^{-3} \mathrm{mM} \mathrm{Mo}$, at $60^{\circ} \mathrm{C}(\mathrm{S110}, 99.9 \%$ recovery, 6-hour loading time, $0.4 \mathrm{~L} / \mathrm{min})$

\begin{tabular}{cccccccc}
\hline Column & $\begin{array}{c}\text { Velocity } \\
(\mathrm{cm} / \mathrm{min})\end{array}$ & $\begin{array}{c}\mathrm{MTZ}_{0.1 \%} \\
(\mathrm{~cm})\end{array}$ & $\begin{array}{c}\text { Column } \\
\text { Length } \\
(\mathrm{cm})\end{array}$ & $\begin{array}{c}\text { Column } \\
\text { Volume } \\
(\mathrm{mL})\end{array}$ & $\begin{array}{c}\text { Sorbent } \\
\text { Weight } \\
(\mathrm{g})\end{array}$ & $\begin{array}{c}\Delta \mathrm{P} \\
(\mathrm{atm})\end{array}$ & $\begin{array}{c}\text { Mo-99/Sorbent } \\
\text { Mass }(\mathrm{Ci} / \mathrm{g})\end{array}$ \\
\hline 5 & 20.13 & 30.1 & 31 & 609 & 791 & 1.09 & 4.54 \\
6 & 13.98 & 20.96 & 22 & 622 & 809 & 0.54 & 4.44 \\
8 & 7.86 & 11.87 & 13 & 653 & 849 & 0.18 & 4.23 \\
10 & 5.03 & 7.67 & 9 & 707 & 919 & 0.08 & 3.91 \\
\hline
\end{tabular}




\section{APPENDIX B:}

\section{pH MEASUREMENTS FOR URANYL SULFATE SOLUTIONS WITH DIFFERENT INITIAL PH VALUES AND DIFFERENT SULFATE CONCENTRATIONS}

TABLE B-1 pH Measurements for Uranyl Sulfate Solutions as a Function of Temperature and Uranium Concentration

\begin{tabular}{|c|c|c|c|c|c|c|c|}
\hline $\begin{array}{l}\mathrm{U}(0.32 \mathrm{M}) \\
\text { Temp. }\left({ }^{\circ} \mathrm{C}\right) \\
\end{array}$ & $\begin{array}{c}\mathrm{SO}_{4}^{2-} \\
(0.60 \mathrm{M}) \\
\mathrm{pH} \\
\end{array}$ & $\begin{array}{l}\mathrm{U}(0.35 \mathrm{M}) \\
\text { Temp. }\left({ }^{\circ} \mathrm{C}\right) \\
\end{array}$ & $\begin{array}{c}\mathrm{SO}_{4}^{2-} \\
(0.58 \mathrm{M}) \\
\mathrm{pH} \\
\end{array}$ & $\begin{array}{l}\mathrm{U}(0.40 \mathrm{M}) \\
\text { Temp. }\left({ }^{\circ} \mathrm{C}\right) \\
\end{array}$ & $\begin{array}{c}\mathrm{SO}_{4}^{2-} \\
(0.67 \mathrm{M}) \\
\mathrm{pH} \\
\end{array}$ & $\begin{array}{l}\mathrm{U}(0.42 \mathrm{M}) \\
\text { Temp. }\left({ }^{\circ} \mathrm{C}\right) \\
\end{array}$ & $\begin{array}{c}\mathrm{SO}_{4}^{2-} \\
(0.72 \mathrm{M}) \\
\mathrm{pH}\end{array}$ \\
\hline 23.4 & 1.24 & 24.0 & 0.99 & 23.1 & 0.98 & 25.4 & 1.06 \\
\hline 50.0 & 1.16 & 30.0 & 0.95 & 30.1 & 1.00 & 30.1 & 1.08 \\
\hline 40.0 & 1.22 & 40.1 & 1.00 & 40.1 & 1.03 & 40.1 & 1.10 \\
\hline 50.0 & 1.25 & 50.1 & 1.04 & 50.0 & 1.03 & 50.0 & 1.11 \\
\hline 60.0 & 1.27 & 60.1 & 1.06 & 60.1 & 1.01 & 60.0 & 1.12 \\
\hline 70.1 & 1.25 & 70.1 & 1.04 & 70.2 & 1.06 & 70.1 & 1.19 \\
\hline 80.4 & 1.20 & 80.3 & 1.04 & 80.0 & 1.00 & 80.0 & 1.11 \\
\hline $\begin{array}{l}\mathrm{U}(0.47 \mathrm{M}) \\
\text { Temp. }\left({ }^{\circ} \mathrm{C}\right) \\
\end{array}$ & $\begin{array}{c}\mathrm{SO}_{4}^{2-} \\
(0.73 \mathrm{M}) \\
\mathrm{pH} \\
\end{array}$ & $\begin{array}{l}\mathrm{U}(0.53 \mathrm{M}) \\
\text { Temp. }\left({ }^{\circ} \mathrm{C}\right)\end{array}$ & $\begin{array}{c}\mathrm{SO}_{4}^{2-} \\
(0.82 \mathrm{M}) \\
\mathrm{pH} \\
\end{array}$ & $\begin{array}{l}\mathrm{U}(0.53 \mathrm{M}) \\
\text { Temp. }\left({ }^{\circ} \mathrm{C}\right) \\
\end{array}$ & $\begin{array}{c}\mathrm{SO}_{4}^{2-} \\
(0.67 \mathrm{M}) \\
\mathrm{pH} \\
\end{array}$ & $\begin{array}{l}\mathrm{U}(0.61 \mathrm{M}) \\
\text { Temp. }\left({ }^{\circ} \mathrm{C}\right)\end{array}$ & $\begin{array}{c}\mathrm{SO}_{4}{ }^{2-} \\
(0.95 \mathrm{M}) \\
\mathrm{pH}\end{array}$ \\
\hline $\begin{array}{l}25.5 \\
30.2 \\
40.0 \\
50.1 \\
60.1 \\
70.0 \\
80.0\end{array}$ & $\begin{array}{l}1.12 \\
1.11 \\
1.13 \\
1.16 \\
1.14 \\
1.19 \\
1.10\end{array}$ & $\begin{array}{l}23.1 \\
30.1 \\
40.0 \\
50.1 \\
60.0 \\
70.0 \\
80.0\end{array}$ & $\begin{array}{l}1.30 \\
1.28 \\
1.29 \\
1.34 \\
1.30 \\
1.31 \\
1.25\end{array}$ & $\begin{array}{l}24.9 \\
30.5 \\
40.3 \\
50.1 \\
60.0 \\
70.1 \\
80.0\end{array}$ & $\begin{array}{l}1.16 \\
1.06 \\
1.12 \\
1.16 \\
1.17 \\
1.17 \\
1.15\end{array}$ & $\begin{array}{l}26.0 \\
30.2 \\
40.0 \\
50.1 \\
60.1 \\
69.9 \\
80.1\end{array}$ & $\begin{array}{l}1.12 \\
1.14 \\
1.17 \\
1.20 \\
1.21 \\
1.23 \\
1.22\end{array}$ \\
\hline $\begin{array}{l}\mathrm{U}(0.40 \mathrm{M}) \\
\text { Temp. }\left({ }^{\circ} \mathrm{C}\right) \\
\end{array}$ & $\begin{array}{c}\mathrm{SO}_{4}^{2-} \\
(0.49 \mathrm{M}) \\
\mathrm{pH} \\
\end{array}$ & $\begin{array}{l}\mathrm{U}(0.40 \mathrm{M}) \\
\text { Temp. }\left({ }^{\circ} \mathrm{C}\right) \\
\end{array}$ & $\begin{array}{c}\mathrm{SO}_{4}^{2-} \\
(0.52 \mathrm{M}) \\
\mathrm{pH} \\
\end{array}$ & $\begin{array}{l}\mathrm{U}(0.43 \mathrm{M}) \\
\text { Temp. }\left({ }^{\circ} \mathrm{C}\right) \\
\end{array}$ & $\begin{array}{c}\mathrm{SO}_{4}^{2-} \\
(0.54 \mathrm{M}) \\
\mathrm{pH} \\
\end{array}$ & $\begin{array}{l}\mathrm{U}(0.45 \mathrm{M}) \\
\text { Temp. }\left({ }^{\circ} \mathrm{C}\right) \\
\end{array}$ & $\begin{array}{c}\mathrm{SO}_{4}^{2-} \\
(0.55 \mathrm{M}) \\
\mathrm{pH}\end{array}$ \\
\hline $\begin{array}{l}27.0 \\
30.1 \\
40.4 \\
50.2 \\
60.2 \\
70.1 \\
80.0\end{array}$ & $\begin{array}{l}1.79 \\
1.67 \\
1.66 \\
1.69 \\
1.70 \\
1.70 \\
1.71\end{array}$ & $\begin{array}{l}27.0 \\
30.4 \\
40.2 \\
50.1 \\
60.3 \\
70.2 \\
80.2\end{array}$ & $\begin{array}{l}1.01 \\
0.90 \\
0.94 \\
0.96 \\
0.98 \\
0.99 \\
1.12\end{array}$ & $\begin{array}{l}25.4 \\
30.8 \\
40.0 \\
50.2 \\
60.5 \\
70.0 \\
80.1\end{array}$ & $\begin{array}{l}1.02 \\
1.07 \\
1.06 \\
1.05 \\
0.99 \\
1.06 \\
1.09\end{array}$ & $\begin{array}{l}25.4 \\
30.8 \\
40.0 \\
50.2 \\
60.5 \\
70.0 \\
80.1\end{array}$ & $\begin{array}{l}1.62 \\
1.63 \\
1.65 \\
1.65 \\
1.68 \\
1.64 \\
1.63\end{array}$ \\
\hline $\begin{array}{l}\mathrm{U}(0.46 \mathrm{M}) \\
\text { Temp. }\left({ }^{\circ} \mathrm{C}\right)\end{array}$ & $\begin{array}{c}\mathrm{SO}_{4}^{2-} \\
(0.57 \mathrm{M}) \\
\mathrm{pH}\end{array}$ & $\begin{array}{l}\mathrm{U}(0.52 \mathrm{M}) \\
\text { Temp. }\left({ }^{\circ} \mathrm{C}\right)\end{array}$ & $\begin{array}{c}\mathrm{SO}_{4}^{2-} \\
(0.66 \mathrm{M}) \\
\mathrm{pH}\end{array}$ & $\begin{array}{l}\mathrm{U}(0.57 \mathrm{M}) \\
\text { Temp. }\left({ }^{\circ} \mathrm{C}\right)\end{array}$ & $\begin{array}{c}\mathrm{SO}_{4}^{2-} \\
(0.68 \mathrm{M}) \\
\mathrm{pH}\end{array}$ & $\begin{array}{l}\mathrm{U}(0.59 \mathrm{M}) \\
\text { Temp. }\left({ }^{\circ} \mathrm{C}\right)\end{array}$ & $\begin{array}{c}\mathrm{SO}_{4}{ }^{2-} \\
(0.78 \mathrm{M}) \\
\mathrm{pH}\end{array}$ \\
\hline 25.0 & 1.22 & 26.0 & 1.12 & 27.0 & 1.24 & 27.1 & 1.07 \\
\hline 30.9 & 1.14 & 30.1 & 1.11 & 30.3 & 1.28 & 30.6 & 1.10 \\
\hline 40.0 & 1.23 & 40.1 & 1.13 & 39.9 & 1.26 & 40.0 & 1.23 \\
\hline 50.1 & 1.27 & 49.9 & 1.13 & 50.1 & 1.28 & 50.0 & 1.27 \\
\hline 60.2 & 1.23 & 60.1 & 1.14 & 60.3 & 1.30 & 60.0 & 1.28 \\
\hline 70.1 & 1.18 & 69.9 & 1.12 & 70.0 & 1.34 & 70.1 & 1.29 \\
\hline 80.1 & 1.18 & 80.1 & 1.13 & 80.0 & 1.39 & 80.1 & 1.30 \\
\hline
\end{tabular}




\section{APPENDIX C:}

\section{VISCOSITY MEASUREMENTS FOR URANYL SULFATE SOLUTIONS}

TABLE C-1 Viscosity Measurements for Uranyl Sulfate Solutions as a Function of Temperature and Uranium Concentration

\begin{tabular}{|c|c|c|c|c|c|c|c|c|c|}
\hline \multicolumn{2}{|c|}{95 g-U/L Uranyl Sulfate } & \multicolumn{2}{|c|}{106 g-U/L Uranyl Sulfate } & \multicolumn{2}{|c|}{110 g-U/L Uranyl Sulfate } & \multicolumn{2}{|c|}{$124 \mathrm{~g}$-U/L Uranyl Sulfate } & \multicolumn{2}{|c|}{141 g-U/L Uranyl Sulfate } \\
\hline $\begin{array}{c}\text { Temperature } \\
\left({ }^{\circ} \mathrm{C}\right)\end{array}$ & $\begin{array}{l}\text { Viscosity } \\
(\mathrm{Cp})\end{array}$ & $\begin{array}{c}\text { Temperature } \\
\left({ }^{\circ} \mathrm{C}\right)\end{array}$ & $\begin{array}{l}\text { Viscosity } \\
(\mathrm{Cp})\end{array}$ & $\begin{array}{c}\text { Temperature } \\
\left({ }^{\circ} \mathrm{C}\right)\end{array}$ & $\begin{array}{l}\text { Viscosity } \\
(\mathrm{Cp})\end{array}$ & $\begin{array}{c}\text { Temperature } \\
\left({ }^{\circ} \mathrm{C}\right)\end{array}$ & $\begin{array}{l}\text { Viscosity } \\
(\mathrm{Cp})\end{array}$ & $\begin{array}{c}\text { Temperature } \\
\left({ }^{\circ} \mathrm{C}\right)\end{array}$ & $\begin{array}{c}\text { Viscosity } \\
(\mathrm{Cp})\end{array}$ \\
\hline 22.6 & 1.23 & 22.9 & 1.25 & 25.1 & 1.22 & 21.9 & 1.38 & 23.1 & 1.39 \\
\hline 30 & 0.99 & 30 & 1.02 & 30.2 & 1.02 & 30 & 1.10 & 30 & 1.15 \\
\hline 40.0 & 0.81 & 40.0 & 0.84 & 40.0 & 0.83 & 40.0 & 0.87 & 40.0 & 0.92 \\
\hline 60.0 & 0.56 & 60.0 & 0.58 & 60.0 & 0.58 & 61.6 & 0.61 & 60.0 & 0.64 \\
\hline 70.0 & 0.49 & 70.0 & 0.54 & 70.0 & 0.57 & 70.0 & 0.58 & 70.0 & 0.59 \\
\hline 78.0 & 0.46 & 80.0 & 0.48 & 80.0 & 0.46 & 80.0 & 0.45 & 80.0 & 0.48 \\
\hline
\end{tabular}





\section{Argonne}

Chemical Science and Engineering Division

Argonne National Laboratory

9700 South Cass Avenue, Bldg. 205

Argonne, IL 60439-4837

www.anl.gov 